-P. Hegedić, M. Jurković, N. Ostojčić, F. Šimunjak

\title{
Popis isplata vojsci u Hrvatskoj i Slavonskoj krajini u listopadu i studenome 1556, prema dvama registrima: prilog istraživanju rane faze vojnokrajiške povijesti
}

\begin{abstract}
Rad donosi popise isplata vojsci u Hrvatskoj i Slavonskoj krajini u listopadu i studenome 1556. godine, transkript izvora te tablicu koja sistematizira u njima navedene podatke. Popraćen je i kratkom uvodnom studijom. U njoj su navedene osnovne informacije o projektu, ishodišnom dokumentu i postojećoj literaturi o temi rane vojnokrajiške povijesti. Studija također donosi kratku analizu struktura vlasti, etničke slike i društvene mobilnosti na Krajini te brojnosti, prostornog razmještaja i opskrbljenosti krajiških utvrda 1556. godine.
\end{abstract}

\section{O projektu}

Akademske godine 2018./2019. na Filozofskom fakultetu Sveučilišta u Zagrebu, u sklopu kolegija „Uvod u istraživački rad. Obrada i vizualizacija demografskih izvora za hrvatsku ranonovovjekovnu povijest ${ }^{\text {"1 }}$, provedeno je istraživanje koje se uglavnom temeljilo na izvorima iz Štajerskog zemaljskog arhiva u Grazu (Steiermärkisches Landesarchiv). ${ }^{2}$ Navedeni izvori sadrže popise isplata vojnicima u Hrvatskoj i Slavonskoj krajini u listopadu i prosincu 1556. godine. Popisi su primarno služili za dokumentiranje isplate plaća pojedinim zapovjednicima i njihovim postrojbama ili nekim drugim krajiškim službenicima poput poštara i špijuna. Međutim, iz ovih se popisa mogu saznati i mnogobrojne druge informacije o funkcioniranju Vojne krajine, primjerice, imena utvrda i njihovih zapovjednika (uključujući i broj vojnika koji je u njima služio), titule pojedinih zapovjednika,

$1 \quad$ Studenti uključeni u rad izbornog kolegija: Petar Hegedić, Monika Hrvoić, Marta Jurković, Leo Levanić, Rebeka Meglić, Nikola Ostojčić, Vanessa Rendić, Karlo Rukavina, Filip Šimunjak, Melani Škrobar, Vinko Udiljak, Teodora-Katarina Valjetić i Antonio Vukelja. Mentorica: prof. dr. Nataša Štefanec.

2 Graz, Steiermärkisches Landesarchiv (dalje: StLA), Laa. A. Antiquum XIV, Sch. 22, 1556/4, 1556-X, sd. - 1556-XI-sd, Particular Verzaichnu $\beta$, auf die zwai Monet October vnd Nouember wie hier In begriffen, Im 1556isten; Isto, 1556-X-29 Warasdin. Spisi nisu numerirani. Koristi se numeracija prepisivača. 
popis dodatnih troškova za posebne usluge, vrste postrojbi (konjica, haramije) ili službenika (poštari, puškari), sjedišta poštarskih postaja i imena članova štaba.

Prvi cilj bila je sistematizacija podataka temeljenih na popisima isplata vojnicima u Hrvatskoj i Slavonskoj krajini u listopadu i prosincu 1556. U tu svrhu svi važni podaci koji se mogu iščitati iz krajiškog popisa uvršteni su u tablicu. To su imena i prezimena pripadnika štaba, poštara, zapovjednika konjice, vojvoda i ostalih krajiških službenika, brojevi vojnika pod određenim zapovjednikom i sveukupne plaće tih postrojbi ili službenika. Drugi cilj bilo je pronalaženje biografskih podataka za što veći broja osoba iz popisa i eventualno njihovih obitelji. Treći je cilj bila detaljna analiza prikupljenih podataka, a četvrti izrada karata Hrvatske i Slavonske krajine na temelju obrađenih podataka.

S pomoću karata pokušali smo zornije predočiti dubinu i širinu krajiškog prostora, a analizom gustoće rasporeda utvrda utvrditi koje su prostore krajiški zapovjednici smatrali važnima i/ili rizičnima. Nadalje, topografska podloga i hidrografska mreža otkrivaju kako su i u kojoj mjeri prirodne prepreke utjecale na razvoj krajiškog prostora. Zbog nedostatka osmanskih izvora za obrađenu godinu (1556), nije bilo moguće rekonstruirati raspored osmanskih utvrda, kao za neka kasnija razdoblja. Spomenuti pristup i izrađene karte omogućuju reinterpretaciju graničnosti krajiškog prostora, kao i dekonstrukciju pojmova granica i omeđenosti u njihovu današnjem, linearnom smislu.

Konačno, peti cilj bio je izraditi internetsku stranicu koja bi široj (i znanstvenoj) javnosti sažeto predstavila sve spoznaje do kojih se istraživanjem došlo. Na njezinoj realizaciji trenutno radi šestero studenata povijesti (i srodnih znanosti), ${ }^{3}$ a osim pregledavanja interaktivnih karata, posjetitelji mogu pročitati i mnoštvo eseja koji se bave širokim spektrom vojnokrajiških tema (razvojem Vojne krajine, utvrdama, načinima ratovanja, krajiškom poštom, zapovjednicima i načinima napredovanja kroz zapovjedne strukture i sl). Rezultati istraživanja redovito se ažuriraju na internetskim stranicama projekta „Bulwark of Europe“. 4

\section{O ishodišnom dokumentu}

Članak analizira Kriegsstaat, vojni proračun ili registar iz 1556. godine. Vojni su proračuni dokumenti koje je periodično sastavljala vojnokrajiška administracija. Riječ je o popisu broja i rodova vojske, njihove plaće, opreme i generalnog financijskog stanja u Vojnoj krajini. Spomenuti proračuni čuvaju se u arhivima u Beču, Grazu, Ljubljani, Budimpešti i Zagrebu. Spis koji analiziramo pohranjen je u Štajerskom zemaljskom arhivu u Grazu (Steiermärkisches Landesarchiv). Proračun iz 1556. jedan je od zasad najranijih pronađenih cjelovitih vojnih proračuna.

\footnotetext{
3 Petar Hegedić, Marta Jurković, Leo Levanić, Nikola Ostojčić, Karlo Rukavina i Filip Šimunjak.

4 https://vojnakrajina.ffzg.unizg.hr/o-krajini/
} 
Radoslav Lopašić objavio je segmente sličnog popisa iz 1555. godine, a objavljeni su i sistematizirani podaci iz proračuna iz 1559. godine, stoga objavljivanje i analiza ovog proračuna upotpunjava prazninu i čini lakšim analizu protostatističke građe koja je često nedosljedna i nepotpuna. ${ }^{5} \mathrm{U}$ planu je i objavljivanje potpunog popisa iz 1555. godine koji se čuva u Grazu.

Za godinu 1556. pronađena su dva dokumenta: popis isplata u Hrvatskoj i Slavonskoj krajini za razdoblje između listopada i prosinca, koji sadrži 28 stranica, te kraći regest koji sadrži popis konjanika i pješaka u Slavonskoj krajini u studenom iste godine, a koji se sastoji od sedam stranica. Dok prvi dokument sadrži sve elemente proračuna, drugi navodi samo brojeve vojnika i rodove vojske, ali bio nam je izuzetno koristan kao kontrolni dokument za prvi, veći spis. Oba su spisa pisana njemačkim pismom (die deutsche Schrift, oblikovano u 16. stoljeću te potječe iz srednjovjekovnoga latinskog pisma - scriptura gothica). ${ }^{6}$ Uočili smo redovita odstupanja u pisanju velikog i malog početnog slova, kratica, interpunkcija i slično. Pri transkripciji koristili smo se preporukama iz Priručnika iz njemačke paleografije autorice Sanje Lazanin. Rukopisi su pisani različitom rukom. U prvom, većem spisu koristi se tipično kancelarijsko pismo onoga vremena, dok je drugi koncept. Spisi nisu numerirani, stoga smo ih sami numerirali te se u transkripciji referirali na svoju numeraciju. Budući da se radi o proračunu, na dnu svake stranice zapisan je zbroj iznosa na toj stranici (Latus), a nakon svake veće sekcije rukopisa također se obračunava međusuma (Idest), što blagajniku olakšava posao. Valja napomenuti da se u dokumentima ovakve naravi upotrebljava terminologija koja još uvijek nije prikladno prevedena na hrvatski jezik.

Ako je suditi prema dostupnoj građi, vojničke plaće sadržane u sličnim proračunima obračunavale su se do 1550-ih godina na sve mjesece u godini, no kasnije je postalo uobičajeno obračunavati ih na devet mjeseci, ponajprije zato što tijekom zimskih mjeseci vojska nije bila angažirana. Za ratnog i poratnog zatišja proračun bi se smanjio. Ponekad bi godinama u funkciji bio jedan te isti proračun, odnosno iznosi i broj vojnika mijenjali bi se minimalno, ako bi se uopće i mijenjali. Načelno, proračune je vojna administracija trebala izrađivati nekoliko puta svake godine. U prvoj polovici stoljeća radili su se najčešće za dvomjesečno razdoblje, a kasnije najčešće nalazimo godišnje proračune. Graničarima su bili namijenjeni srebrni rajnski guldeni. Ipak, novac bi nerijetko kasnio ili dolazio u obliku platna i hrane, što se vojnicima odbijalo od osnovne plaće. Ratno profiterstvo bilo je neminovan ishod.

Spisi kao što su Kriegsstaat sadrže raznovrsne podatke: imena i prezimena ljudi iz viših vojnih slojeva, njihove titule, službe, podatke o plaćama vojnika i njihovoj opremi, mjestu služenja, opremljenosti krajiških postrojbi u različitim

LOPAŠIĆ 1885: 151-232 (215-217); ŠTEFANEC 2011: 466-474.

6 LAZANIN 2004: 33. 
utvrdama, podatke o utvrdama koje su u funkciji i slično. Vrve toponomastičkim, dijalektološkim te podacima idealnim za migracijske studije iz kojih je moguće povući smjernice za neka buduća istraživanja. ${ }^{7}$

\section{Literatura}

O ustrojstvu i oblikovanju Hrvatske i Slavonske vojne krajine do sada je napisano podosta znanstvene literature, ali istaknut ćemo studije kojima smo se intenzivnije koristili. Iznimno nam je korisna bila i starija literatura, pri čemu ističemo radove Emilija Laszowskog, Radoslava Lopašića, Matije Mesića i Gjure Szabe. Laszowski daje regionalni opis razvoja pojedinih mjesta na području Gorskog kotara u kasnom srednjem i ranom novom vijeku. ${ }^{8}$ Lopašić također u svojim radovima piše regionalnu povijest, ali se usredotočuje na prostor Bihaćke krajine i područja oko rijeka Kupe i Korane. ${ }^{9}$ Njegovi radovi pretežito opisuju razdoblje turskih provala početkom 16. stoljeća. Mesić se bavio izdavanjem izvorne građe te životom i djelom Nikole Zrinskog Sigetskog, dok Szabo u svojem djelu daje prikaz većine gradova na području Hrvatske i Slavonije. ${ }^{10}$ Svi navedeni radovi sadrže mnogobrojne slike i tlocrte pojedinih gradova i utvrda.

Od novije literature treba istaknuti radove Andreja Hozjana, Ivana Jurkovića, Karla Kasera, Milana Kruheka, Géze Pálffyja, Vaska Simonitija i Nataše Štefanec, koji sadrže informacije o cijelom nizu aspekata povijesti Vojne krajine. Kruhek se posebno osvrće na vojnopovijesne aspekte poput utvrda i načina ratovanja. ${ }^{11}$ Kaser se u dvotomnom djelu usredotočio na upravne, društvene i gospodarske aspekte Vojne krajine od njezina osnutka pa sve do ukidanja u 19. stoljeću. ${ }^{12}$ Štefanec također naglašava organizacijske, upravne i društvene procese i reforme koji su se odvijali na području Krajine u drugoj polovini 16. stoljeća. ${ }^{13}$ Simoniti se u svom radu usredotočio na niz društvenih, vojnih i administrativnih aspekata vezanih za prodor osmanskih trupa na područje slovenskih zemalja te na ulogu navedenih zemalja u financiranju Vojne krajine. ${ }^{14}$

Doktorska disertacija Ivana Jurkovića bila je također značajna u istraživanju. ${ }^{15}$ U njoj je iznesena kratka povijest važnijih hrvatskih plemićkih obitelji u razdoblju

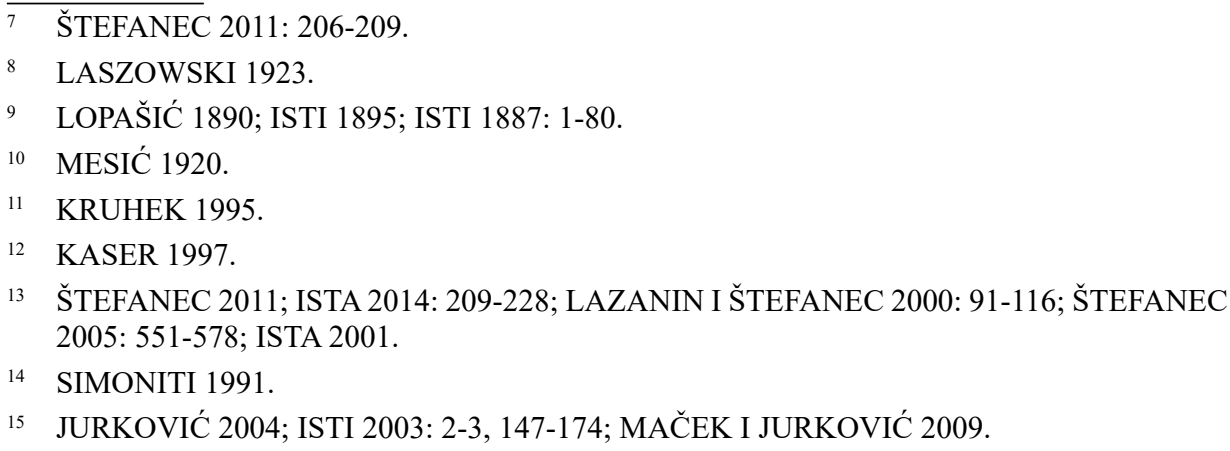


osmanskih prodora na hrvatsko područje tijekom 15. i 16. stoljeća te posljedične promjene s kojima su se pripadnici plemićkih obitelji suočavali, kao što su migracije i promjene njihova društvenog položaja. Završno treba spomenuti monografiju i članke Andreja Hozjana. ${ }^{16}$ U njima je objašnjen nastanak i razvoj poštanskog sustava te način na koji je taj sustav funkcionirao na području Hrvatske i Slavonske vojne krajine. Monografija sadrži karte poštanskih ruta s označenim poštanskim postajama. U njoj možemo naći i popise poštara iz 16. i 17. stoljeća te njihove kratke biografije.

Temu je u nizu članaka obrađivao i Géza Pálffy. Posebno je analizirao osnivanje, organizaciju i financiranje Vojne krajine (uključujući i Hrvatsku i Slavonsku krajinu) u 16. stoljeću, financijske poteškoće koje je ona zadavala Bečkom dvoru te odnose lokalnog plemstva s Bečkim dvorom. Za naše su istraživanje od posebne važnosti popisi zapovjednika i karte Vojne krajine iz 16. i 17. stoljeća koje Pálffy prilaže u svojim člancima. ${ }^{17}$

\section{Kratka analiza}

Iako registri ne imenuju izrijekom svakog pojedinog vojnika, podaci koje takvi dokumenti donose ipak omogućuju kratku analizu struktura vlasti, etničke slike te društvene mobilnosti u Vojnoj krajini. Povedemo li se klasifikacijom krajiških elita koju su u svojem članku ponudile Danijela Cofek i Nataša Štefanec, godine 1556. na Krajini možemo raspoznati dvije skupine: više vojne i administrativne dužnosnike koji su bili regrutirani iz redova unutrašnjoaustrijskih staleža, no ne iz najviših barunskih plemićkih slojeva, te pripadnike domaćih elitnih slojeva. ${ }^{18}$ Promotrimo li imena pripadnika vrhovnoga štaba Slavonske i Hrvatske krajine, uočit ćemo da su, izuzev Ivana Lenkovića, glavnog zapovjednika, svi austrijskog podrijetla. Premda su, kao što i samo ime kaže, Krajinu činili izvorno hrvatski i slavonski prostori, ne treba začuditi prevlast austrijskog elementa u vladajućoj strukturi. Naime, upravo je 1556. godine osnovano Dvorsko ratno vijeće u Beču, kojemu je povjeren zadatak osmišljavanja obrambene strategije i rukovanja pozamašnim novčanim sredstvima koja su Dvorska komora i staleži Unutrašnje Austrije namijenili financiranju krajiške vojske. Austrijski su staleži stoga, očekivano, na Krajini htjeli imati vlastite ljude, o čemu svjedoče i funkcije ratnih savjetnika iz Kranjske i Koruške, među kojima je bio Veit von Hallegg, kasnije dugogodišnji glavni zapovjednik Slavonske krajine. ${ }^{19}$

$16 \quad$ HOZJAN 2017; ISTI 2002; ISTI 2009: 263-276.

17 PÁLFFY 2001: 183-220; ISTI 2002: 99-131; ISTI 2004: 17-40; ISTI 2003a: 463-504; ISTI 1997: 257-287; ISTI 2003b: 111-148; ISTI 1995: 114-185; ISTI 1999: 331-367. Karte v. u: ISTI 2011; ISTI 2000.

18 COFEK I ŠTEFANEC 2011: 13-16.

19 Ibid.: 6, 13; ŠTEFANEC 2011: 202-203. 
Promotrimo li, međutim, zapovjednike lake konjice, u mnogima od njih prepoznat ćemo pripadnike lokalne elite, bilo hrvatskog, bilo ugarskog podrijetla. Ukratko, riječ je o skupinama kojima je očuvanje Krajine bilo u interesu, ponajprije zato što su se njihova obiteljska dobra, koja vlastitim snagama nisu mogli obraniti pred Osmanlijama, nalazila upravo na tim prostorima. Tako popis iz 1556., uz bana Nikolu Zrinskog i budućeg bana Krstu Ungnada, spominje i Ivana Alapića, Petra Ratkaja te Luku i Jakova Sekelja, pripadnike obitelji kojima je upravo tijekom 16. stoljeća dodijeljena barunska titula. ${ }^{20}$ Popis ne donosi vijest o zapovjednicima teške konjice, ali popisuje harambaše, tj. vojvode i broj njima podređenih haramija. Već 1556. godine uočljiv je među harambašama slavenski element koji potvrđuje prethodno spomenute migracije, koje su podupirali austrijski staleži. Tako nisu neobična prezimena poput Preskočilović (Preskhotschilouitsch), Vlah (Blach) i Pribeg (Pribegg), koja svjedoče o prebjegličkom/izbjegličkom statusu onih koji su ih nosili. Nadalje, da je mobilnost na Krajini bila ne samo prostorna već i društvena, potvrđuje i slučaj obitelji Margetić, koja se vojnom službom iz harambaških uzdignula u plemićke redove.

Margetići su se, inače pravoslavne vjeroispovijesti, na prostor Kraljevine Slavonije - preciznije, u Križevačku županiju - najvjerojatnije doselili između 1542. i 1551. godine. Predvodio ih je vojvoda Ivan Margetić (Rascianus), koji je zapovijedao s 49 konjanika. ${ }^{21}$ Isti Ivan Margetić (Ibänn Margettitsch) spominje se u popisu iz 1556. godine kao zapovjednik lake konjice u Koprivnici, ravnajući šezdesetoricom konjanika, dok je njegov brat Plavac (Plauez Margetitsch), inače harambaša, pod svojim zapovjedništvom imao pedesetoricu haramija, također u Koprivnici. Tri godine kasnije Plavac je i sâm postao zapovjednikom lake konjice, i dalje u Koprivnici, također ravnajući šezdesetoricom konjanika, dok popis iz 1577. godine Ivana Margetića ponovno uvrštava među značajnije vojskovođe. ${ }^{22}$ Iako popis iz 1630. ne donosi vijest o Margetićima, isto se ne može reći i za Bojničićev Der Adel von Kroatien und Slavonien, koji popisuje plemićke obitelji Hrvatske i Slavonije, u čije su redove Margetići stupili zahvaljujući plemićkoj povelji koju im je 1646. godine dao kralj Ferdinand III. ${ }^{23}$

Kad govorimo o ljudstvu, preostaje nam osvrnuti se na vojnike koji nisu poimence spomenuti u popisu, a koji su činili većinu snaga na Krajini. Postrojbe su se dijelile na pješake i konjanike, u omjeru $1: 1$. U pješake ubrojili smo

20 Redom 1555., 1559. i 1596. godine. Usp. Hrvatska enciklopedija, s. v. „Alapić“, „Ratkaj“ i „Székely“; HOZJAN 2010: 153-168.

21 PETRIĆ 2016: 204.

22 ŠTEFANEC 2011: 467; Muster lista, 1577.: Graz, StLA, Laa A. Antiquum XIV Militaria, 1577-VIII-24-Warasdin (http://www.ffzg.unizg.hr/pov/zavod/demografija/?q=node/3 (posjet 28. 1. 2019)).

23 BOJNIČIĆ 1899: 111. 
zapovjedno osoblje, haramije, njemačke pješake, izviđače, puškare te vratare i stražare. Prema podacima iz popisa, pod zapovjednicima služilo je 768 pješaka i haramija te još šezdesetorica kao „tvrđavna posada“. Potrebno je napomenuti da je plaćenih haramija i pješaštva gotovo sigurno bilo i više. Naime, popis za većinu utvrda donosi tek iznos zapovjedničke plaće, no ne i broj vojnika kojima je pojedini harambaša zapovijedao, dok za neke zapovjednike ne donosi vijest ni o rodu ni o brojnosti postrojba kojima su zapovijedali. Također, nije točno poznat ni etnički omjer pješačkih postrojbi: popis samo navodi da su u Varaždinu i Zagrebu bili stacionirani i njemački i hrvatski/slavonski pješaci. Puškari, njih dvanaestorica, bili su stacionirani u Đurđevcu (2), Koprivnici (1), Križevcima (1), Varaždinu (6), Hrastovici (1) i Sisku (1). Zanimljivo je primijetiti i da su puškari mahom bili Austrijanci, uglavnom locirani u Varaždinu, što vjerojatno svjedoči o činjenici da su bili bolje upoznati s novim tehnologijama (tj. vatrenim oružjem) od svojih slavenskih suboraca. Osmorica izviđača bila su pripadnici tvrđavnih posada Đurđevca (2), Hrastovice (2), Svinice (2) i Steničnjaka (2), kao i vratari i stražari (ukupno njih 34, od kojih 22 u Đurđevcu i 12 u Koprivnici), koje popis ne razlikuje te ih stoga vodimo kao jedinstvenu kategoriju. Minimalan broj pješaka u Vojnoj krajini 1556. godine kretao se, dakle, oko 920 vojnika, dok je točnija procjena otprilike 1.000 do 1.100 pješaka.

Konjanici su uglavnom pripadali lakoj konjici, a bilo ih je 1.045. Najvećim brojem konjanika zapovijedali su lokalni moćnici. Pod Székelyma bila su 225 konjanika, od kojih je 200 bilo stacionirano u Körmendu, a pod Krstom Ungnadom 132, od kojih 100 u Koprivnici. Po 100 konjanika bilo je pod Nikolom Zrinskim (u Csurgu) i Ladislavom Kérecsenyijem u Cirkveni. Ukupno gledano, najviše se pripadnika lake konjice nalazilo u Körmendu (200), Koprivnici (190), Križevcima (180) te Csurgu (100) i Cirkveni (100). U unutrašnjosti, na austrijskom prostoru (u Veržeju, Ljutomeru, Radkersburgu i Fürstenfeldu), nalazilo se i šest ,zastava“ teške konjice, tj. 600 konjanika koji su mogli biti dignuti prema potrebi, a redovito ih se plaćalo. Iz popisa doznajemo i da je krajiška pošta imala 13 postaja, ali ne i točan broj poštanskih konja, kao ni jesu li sve postaje imale poštara (bilo konjanika, bilo pješaka). U konačnici, dakle, možemo zaključiti da se 1556 . godine na Krajini nalazilo između 1.965 i 2.145 plaćenih vojnika, od kojih je otprilike jedna polovica služila u pješaštvu, a druga u konjaništvu. Ako se taj broj usporedi s banskom četom u kojoj je bilo oko 1.000 ljudi, radi se o znatnoj vojnoj sili na stalnom raspolaganju krajiškim vlastima.

Na kraju, valja ukratko prokomentirati i utvrde spomenute u registrima obrađenima u ovome radu. Uspješno smo locirali 34 poznate utvrde, od kojih 30 na prostoru Vojne krajine, koje su se razlikovale prema veličini vojnih postrojbi i sastavu. Treba napomenuti kako registri nisu potpuni te da je problem predstavljalo nenavođenje broja vojnika, unatoč zabilješci o postojanju vojske u pojedinoj utvrdi, kao i zapisi o zajedničkim zbrojevima utvrda. Problem su predstavljala i imena mjesta. 
Naime, ondje gdje nije bilo moguće sa sigurnošću utvrditi o kojoj je utvrdi riječ, do odgovora došli smo usporedbom s drugim registrima i ostalim zapisima. Kako bismo bolje prikazali važnost pojedinih utvrda, usporedili smo proračun iz 1556. s proračunima iz 1554., 1559., 1564., 1565., 1573., 1576. 1577. i 1578. godine. ${ }^{24}$

Utvrde s najvećim brojem konjanika, prema registru iz 1556. godine, bile su Körmend (200), Koprivnica (190), Križevci (180) te Ljutomer (200) i Veržej (200) u unutrašnjosti. Posebno treba istaknuti Ljutomer, Körmend i Veržej kojima se, iako je u njima 1556. godine bila locirana teška naoružana konjica, u idućim registrima izgubio trag jer je većina plaćene vojske smještena na sâm krajiški prostor. S druge strane, Križevci, koji su uz brojnu konjicu imali i velik broj haramija (119, brojno nadmoćniji glede haramija bio je samo Siget sa 168), s vremenom su sve više jačali. Ta činjenica, međutim, ne iznenađuje, s obzirom na to da se 1552. godine granica neposredno približila Križevcima i ozbiljno ugrozila grad koji se stoga pretvarao u tvrđavu. ${ }^{25}$ Već 1554 . godine zabilježeno je 66 konjanika i 39 pješaka. Kao najvažnija crta obrane između Save i Drave, Križevci su se kontinuirano bilježili pa se tako 1578. godine prvi put jasno ističu kao središte kapetanije (Cirkvena i Gradac pripadaju Križevačkoj kapetaniji) s moćnom posadom od 150 haramija, 120 njemačkih pješaka, 50 njemačkih konjanika (arkebuzira) i 50 husara. Koprivnica, kao i Križevci, bilježila je značajan rast vojnih kontingenata tijekom godina te je također postala središtem kapetanije (Koprivnička kapetanija), što je zapisano u registru iz 1578. Koprivničkoj kapetaniji pripadali su tada, od utvrda iz registra iz 1556., Ludbreg, Topolovac i Đurđevac. ${ }^{26}$

U registru iz 1556. nalaze se i druge utvrde koje su kasnije postale središtima kapetanija. Tako je za Hrastovicu zabilježeno da je kapetanijom postala već 1564. godine te je iste godine i Vinodol upisan kao dio Hrastovičke kapetanije, dok je Ivanić Grad zabilježen kao središte kapetanije 1578. godine. Sva središta kapetanije 1578. bila su opskrbljena husarima, što nije bio slučaj ni za jednu utvrdu zabilježenu u popisu iz 1556. godine, što govori o novim taktičkim odlukama vojnog vrha $\mathrm{u}$ Beču. ${ }^{27}$ Promjene granica Vojne krajine i promjena važnosti pojedinih utvrda u njoj bila je vrlo dinamična. To dokazuje i podatak da se $38 \%$ utvrda, njih 13 od ukupno 34 (tj. 43\%, ako za konačan broj utvrda uzmemo onih 30 na krajiškom ozemlju), nakon godine 1556. nije spominjalo u kasnijim registrima. Isto tako, novi sustav organizacije Krajine te formiranje kapetanija progovara o utvrdama kojima je porasla važnost.

24 LOPAŠIĆ 1887: 1-81; ŠTEFANEC 2011: 465-494.

25

BEDENKO 1993: 78-79.

26 ŠTEFANEC 2011: 396-410.

27 Graz, StLA, Laa. A. Antiquum XIV, Sch. 22, 1556/4, 1556-X, sd. - 1556-XI-sd, Particular Verzaichnuß, auf die zwai Monet October vnd Nouember wie hier In begriffen, Im 1556isten (Spis nije numeriran. Koristi se numeracija prepisivača); ŠTEFANEC 2011: 396-410. 
Konačno, kao što je razvidno u tablicama priloženima radu, valja istaknuti da je ukupan trošak održavanja Hrvatske i Slavonske vojne krajine samo u listopadu i studenome iz 1556. godine, prema obrađenim registrima, iznosio 19.864 talira, 28 krajcara i 2 denara, što je ogroman iznos u kontekstu Hrvatsko-slavonskog Kraljevstva u kojem je godišnji iznos prikupljene dike, glavnog poreza u Kraljevstvu, iznosio oko 4.000 dukata.

\section{Zaključak}

U nastavku teksta donosimo tablicu koja sistematizira podatke iz dvaju izvora, izvore i transkripte izvora u nadi da će koristiti budućim istraživačima.

Prilog 1. 1. Transkript prvog dokumenta krajiškog popisa za 1556. godinu

\section{Signatura}

Graz, Steiermärkisches Landesarchiv, Laa. A. Antiquum XIV, Sch. 22, 1556/4, 1556-X, sd. - 1556-XI-sd

\section{Regesta}

Popis isplata vojsci u Hrvatskoj i Slavonskoj krajini u listopadu i prosincu 1556. godine, prema važećem muster-registru (28 str). Spis nije numeriran. Koristi se numeracija prepisivača.

Particular Verzaichnuß, auf die zwai Monet October vnd Nouember wie hier In begriffen, Im 1556isten (1)

Particular Verzaichuß mein Georgen Peogl Freiherrn zu Reiffenstain vnd Arberg u[nd] ainer Ersamen Landtschafft in Steier Khriegszalmaister an dem Windischen vnd Chrabatischen Gränizen Aüßgab Auf vollige Auszallunng Wolgedacher Landtschafft Khriegsvolgkh Innhallt des Befertigten Musster Register Auf die 2 Monnett Octoberis vnnd Nouembris Jezlauffenntes Sehsundfinffzigisten Jars wie volgt etc.

\section{Erstlichen auff den herrn Obrissten vnd annder Khriegs Officier}

No 1 Dem herrn Obristen Inhalt des Musster Register vnnd seiner Quittung auf der Obgemelten zwai Monnet October vnnd Nouember zallt $800 \mathrm{t}-\mathrm{d}$

No 2 Wallthausern von Wallterstain verbalten des Leüttenambts Ambt Innhalt des Musster Register vnnd seine Quittung 2 Monet zalt $80 \mathrm{t}-\mathrm{d}$

No 3 Herrn Veythen von Hallegg Ainer Ersamen Landtschafft aus Chärnnten Khriegs Rath sein leibsbesoldung vnnd auf seine siben Phärt Inhalt des Musster Register vnd seiner Quittung zalt $212 \mathrm{t}-\mathrm{d}$

Latus $1092 \mathrm{t}-\mathrm{d}(2)$ 
No 4 Wallthauser Khazianner Ainer Ersamen Lanndtschafft in Chrainn khriegs Ratt sein Leibsbesoldung vnd Auf seine 8 Phärdt. Innhalt des Musster Register vnnd seiner Quittung 2 Monet zallt $228 \mathrm{t}-\mathrm{d}$

N 4 Mein Georgen Peögl Leibsbesoldung vnnd auf 12 Meiner gerüssten phärt Inhalt des Muster 2 Monnet $292 \mathrm{t}-\mathrm{d}$

No 5 Dem herrn Obrissten Auf des khriegs Secretari Ambt Innhalt des Musster Regisster vnnd seiner Quittung 2 Monnet bezalt $64 \mathrm{t}-\mathrm{d}$

No 6 Jacoben Plochnner Musster schreiber Innhalt des Musster Register vnd seiner Quittung sein Leibsbesoldung Auf 2 Monnet zalt 20t - d

Latus $604 \mathrm{t}-\mathrm{d}(3)$

No 7 Hercälusen Erd des herrn Obristen veld Trommetter Innhalt des Musster Register vnnd seiner Quittung 2 Monnet zallt $32 \mathrm{t}-\mathrm{d}$

No 8 Hannsen des herrn obristen Heörpaugger Innhalt des Musster Register vnnd seiner Quittung 2 Monet zalt $32 \mathrm{t}-\mathrm{d}$

Latus $64 \mathrm{t}-\mathrm{d}$

Suma summarum aller Vorgeschribnner Ausgab auf den herrn Obristen vnnd Annder khriegs Officier Thuet Ain Tausent Sibnnhund[er]t sechzig phundt phennig Idest $1760 \mathrm{t}-\mathrm{d}(4)$

\section{Ausgab auff die Posstphärdt}

No 9 Lucas Zellenngge Postfürdrer Zu Lebe Innhalt des Musster Register vnnd seiner Quittung 2 Monet zalt $20 \mathrm{t}-\mathrm{d}$

No 10 Ischtuan Pridoieuitsch Postfürdrer zu Lümbach Innhalt des Musster Register vnnd seiner Quittung 2 Monet zalt $20 \mathrm{t}-\mathrm{d}$

No 11 Ianuschen gusmitsch Postfürdrer zu Warasdinni Innhalt des Musster Register vnnd seiner Quitting 2 Monat zalt $48 \mathrm{t}-\mathrm{d}$

No 12 Ibann Medagkh Posstfürdrer zu Lepaglaue Innhalt des Musster Register vnd seiner Quittunng 2 Monnatt zalt $20 \mathrm{t}-\mathrm{d}$

No 13 Michel schischkho Posstfürdrer zu heiligen khreitz Innhallt des Musster Register vnnd seiner Quittung 2 Monnet zallt $20 \mathrm{t}-\mathrm{d}$

Latus $128 \mathrm{t}-\mathrm{d}(5)$

No 14 Larennz Cornnitschitsch Postfürdrer zu Agram Innhalt des Musster Register vnnd seiner Quittung Auf 2 Monnet $30 \mathrm{t}-\mathrm{d}$

No 15 Michel Guettlich Postfürderer zu Pethau Innhalt des Musster Register vnnd seiner Quittung 2 Monat zallt $24 \mathrm{t}-\mathrm{d}$

No 16 Bartlmee fleischhagkher Postfürdrer zu Marchburg Innhalt des Musster Register vnnd seiner Quittung zalt 2 Monat $24 \mathrm{t}-\mathrm{d}$

No 17 Paull Diuiagkh Postfürdrer zu der Lanndtscha Prugkhen Innhalt des Muster Register vnd seiner Quittung 2 Monet zalt $40 \mathrm{t}-\mathrm{d}$

No 18 Veytthen Plaschg Postfürdrer zu Rattkherspurg Innhalt des Musster Register vnnd seiner Quittung zalt annd[er]halb Monet zalt $18 \mathrm{t}-\mathrm{d}$

No 19 Janusch Mälikhozi Postfürdrer zu Razkhanischa Innhalt des Musster Register vnnd seiner Quittung And[er]halb Monet zalt $18 \mathrm{t}-\mathrm{d}$

Latus $154 \mathrm{t}-\mathrm{d}(6)$

No 20 Petter Bambosch Postfürdrer zu Prelogkh Innhalt des Musster Register vnd seiner Quittung Ił Monet zallt $18 \mathrm{t}-\mathrm{d}$ 
P. Hegedić, M. Jurković, N. Ostojčić, F. Šimunjak - Popis isplata vojsci u Hrvatskoj i Slavonskoj...

No 21 Georgen Tanngitsch Postfürdrer zu Letenna Innhalt des Musster Register vnnd seiner Quittung Ił Monet zalt $15 \mathrm{t}-\mathrm{d}$

Latus $33 \mathrm{t}-\mathrm{d}$

Suma summarum aler vorgeschribner Ausgab Auf die Postphärdt Thuett dreühunndert finfzehen Phundt Phennig

Idest $315 \mathrm{t}-\mathrm{d}(7)$

Ausgab auff die gehaimen khunndtschaffter

No 22 Darauff Innhalt des herrn Obrissten Verfertigten Particular Auf das Monnet Nouember vnnd december bezallt zwaihundert dreüundzwainzig phundt dreissig khreizer.

Idest 223 t $30 \mathrm{kr}(8)$

\section{Aufgab auff die geringen Phärdt}

No 23 Herrn Jacoben Zägkhl auf seines herrn Vattern ainhundert geringe Phärt Inhalt des Musster-Register vnnd seiner Quittung 2 Monett zalt $916 \mathrm{t}-\mathrm{d}$

No 24 Item Ime herrn Jacoben Zägkhl auf seine 100 gerinngen Phärdt 2 Monnet Inhalt des Musster-Register vund seiner Quittung 2 Monet zalt $916 \mathrm{t}-\mathrm{d}$

No 25 Herrn Cristoffen vngnaden Auf seine 100 Phärt Innhalt des Musster Register vnnd seiner Quittung, 2 Monnet zallt $916 \mathrm{t}-\mathrm{d}$

No 26 Herrn Niclasen Graffen zu Serinn etc. Wann etc. auf seine 100 geringe Phärt Inhalt des Muster Register vnnd seinner Quitung 2 Monet zallt $916 \mathrm{t}-\mathrm{d}$

Latus: $3664 \mathrm{t}-\mathrm{d}(9)$

No 27 Pettern Cästilampfi Auf herrn Jobst Josephen won Thurn Phärt Inhalt des Muster Register vnnd seiner Quitung 2 Monett zalt $538 \mathrm{t}-\mathrm{d}$

No 28 Herrn Hannsen Allapi Auf seine 60 gerinngen Phardt Inhalt des Musster Register vnnd seiner Quitung 2 Monnet zallt $556 \mathrm{t}$ - d

No 29 Herrn Hannsen Gessti Auf seine 60 gerinngen Phärt Innhalt des Musster Register vnnd seiner Quittung, 2 Monet zalt $556 \mathrm{t}-\mathrm{d}$

No 30 Niklasen Bradatschen Auf seine 60 geringen Phert Inhalt des Musster Register vnnd seiner Quittung, 2 Monet zallt $556 \mathrm{t}-\mathrm{d}$

No 31 Pettern Radtkhay Auf seine 60 gerinngen Phärt Innhalt des Musster Register vnd seiner Quittung 2 Monet zalt $556 \mathrm{t}-\mathrm{d}$

Latus: $2762 \mathrm{t}-\mathrm{d}(10)$

No 32 Ibänn Margettitsch Auf seine 60 gerinngen phärt, Inhalt des Musster Register vnnd seiner quittung 2 Monet zalt $556 \mathrm{t}-\mathrm{d}$

No 33 Tomäschen Salbay Auf seine 28 phärdt, Innhalt des Musster Register vnd seiner Quittung 2 Monat zalt $252 \mathrm{t}-\mathrm{d}$

No 34 Lässlo Kherenntschini auf seine 100 gerinngen phärdt, Inhalt des Musster Register vnnd seiner Quittung 2 Monet zalt $916 \mathrm{t}-\mathrm{d}$

No 35 Herrn Lucasen Zägkhl freih[er]rn zu Fridau Annstat Sallay Clement auf seine 25 phärdt, Inhalt des Musster Register vnd seiner Quittung zalt 2 Monet $225 \mathrm{t}-\mathrm{d}$ No 36 Steffann Turözi Auf seine 20 gerinngen phärdt, Innhalt des Musster Register vnd seiner Quittung 2 Monet zallt $180 \mathrm{t}-\mathrm{d}$

Latus $2129 \mathrm{t}-\mathrm{d}(11)$ 
No 37 Janusch Pekheri Auf seine 20 gering[en] phärdt, Innhalt des Musster Register vnnd seiner Quittung 2 Monnet zallt $180 \mathrm{t}-\mathrm{d}$

No 38 Herrn Cristoffen Vnngnaden Auf die 32 gerinngen phärt so zu behuet des geschloss Warasdinni gehalten werd[en], Innhalt des Musster Register vnnd seiner Quitung 2 Monett zallt $288 \mathrm{t}-\mathrm{d}$

No 39 Caspernn Gottallen haubtman zu sant Geörgen, Auf die 30 phärt so Alda geholten werden Inhalt des Musster Register vnnd seiner Quitung zallt 2 Monnet $236 \mathrm{t}-\mathrm{d}$

No 40 Lässlo Rittschaun haubtman zu Copreiniz, Innhallt des Musster Register vnnd seiner Quittung, Auf die 30 geringen phärdt so Alda gehalten werden 2 Monnet zallt $240 \mathrm{t}-\mathrm{d}$

No 41 Manngfredo Manüago haubtman vnnd Janusch od Nemez Fendrich vber die haramia zu Ross, Innhalt Irer Quittung[en] 2 Monnet zallt 444 t - d

Latus $1388 \mathrm{t}-\mathrm{d}(12)$

Suma summarum aller vorgeschribnner Ausgab Auf die gering gerüssten phärt, Thuett Neün

Tausent Neünhund[er]t dreü und vierzig phundt phennig

Idest $9943 \mathrm{t}-\mathrm{d}(13)$

\section{Ausgab auf die haramia vnd Ire Voyuoda}

No 42 Lasslo Naig Voÿuoda Auf Inn vnnd seine vntergebnen haramia Inhalt des Musster Register vnd seiner Quittung 2 Monet zallt $190 \mathrm{t}-\mathrm{d}$

No 43 Jeörgen Khappä Voyuoda auf Im vnnd seine vnntergegebne haramia Inhalt des Musster Register vnd seiner Quittung 2 Monet zallt $177 \mathrm{t}-\mathrm{d}$

No 44 Pettern Sremäz Voyuoda Auf Im vnnd seine vnntergebnen haramia Innhalt des Musster Register vnnd seiner Quittunng 2 Monett zallt $177 \mathrm{t}-\mathrm{d}$

No 45 Rädtkho Prÿbeg Voyuoda Auf Im vnnd seine vnntergebne haramia Innhalt des Musster Register vnnd seiner Quittung 2 Monet zalt $238 \mathrm{t}-\mathrm{d}$

No 46 Plauez Margetitsch Voyuoda Auff Im vnnd seine vnntergebne haramia Innhalt des Musster Register vnnd seiner Quittung 2 Monet zallt $283 \mathrm{t}-\mathrm{d}$

Latus $1065 \mathrm{t}-\mathrm{d}$ (14)

No 47 Petter Chorannthey Voyuoda Auff Im vnnd seine vnntergegebnen haramia Inhalt des Musster Register vnnd seiner Quittung 2 Monet zalt $213 \mathrm{t}-\mathrm{d}$

No 48 Annthall Copinnßkhi voyuoda auf Im vnnd seine vnndtergebne häramia Innhalt des Musster Register vnnd seiner Quittung 2 Monnet zalt $254 \mathrm{t}-\mathrm{d}$

No 49 Pettern Traschkhowitsch voyuoda Auf Im vnnd seine vntergegebnen häramia Innhalt des Musster-Register vnnd seiner Quittung 2 Monnet bezallt $187 \mathrm{t}-\mathrm{d}$ No 50 Jurgkho Woiaffzänn voyuoda Auf Im vnnd seine vnntergegebnen haramia Innhalt des Musster Register vnnd seiner Quittung 2 Monnet zallt $245 \mathrm{t}-\mathrm{d}$

No 51 Jeörgen Lettella voyuoda Auf Im vnnd seine vnntergebnen Haramia Inhalt des Musster Register vnnd seiner Quittung 2 Monet zalt $281 \mathrm{t}-\mathrm{d}$

Latus $1180 \mathrm{t}-\mathrm{d}(15)$

No 52 Ibann Nouägkh voyuoda Auf Im vnnd seine vnntergebnen Haramia Innhalt des Musster Register vnd seiner Quittung 2 Monet zallt $306 \mathrm{t}-\mathrm{d}$

No 53 Räde prybeg voyuoda Auf Im vnnd seine vnntergebne haramia Inhalt des Musster Register vnnd seiner Quittung 2 Monnet zallt $273 \mathrm{t}-\mathrm{d}$ 
P. Hegedić, M. Jurković, N. Ostojčić, F. Šimunjak - Popis isplata vojsci u Hrvatskoj i Slavonskoj...

No 54 Tomash od Schanndrofza voyuoda Auf Im vnnd seine vnntergebnen Haramia Innhalt des Musster Register vnnd seiner Quittung 2 Monnet zalt $213 \mathrm{t}-\mathrm{d}$

No 55 Jurgkho Sgottschewitsch voyuoda Auf Im vnnd seine vntergebnen Haramia Innhalt des Musster Register vnd Seiner Quittung 2 Monet zallt $157 \mathrm{t}-\mathrm{d}$ No 56 Anndreas Copiär voyuoda Auf Im vnnd seine vnntergebnen Haramia Innhalt des Musster Register vnnd seiner Quittung 2 Monet zalt $157 \mathrm{t}-\mathrm{d}$

Latus $1106 \mathrm{t}-\mathrm{d}(16)$

No 57 Frannzen Tächi Auf Niclos Cottschekharütsch Voyuoda vnnd seine vnntergebnen häramia zu Wiswär Innhalt des Musster RegisterRegistervnnd seiner Quittung 2 Monet zallt $197 \mathrm{t}-\mathrm{d}$

No 58 Marco Blach voyooda Auf Im vnnd seine vnntergebnen Haramia Inhalt des Musster Register vnnd seiner Quitung, von dem 8. Nouember so Er Aufgenumen zu Endt des selben 3 Wochen bezallt 73 t $7 \beta-d$

No 59 Mathiasch Märkhouitsch Voyuoda Auf Im vnnd seine vnntergebnen Höramia Inhalt des Musster Register vnnd seiner Quittung 3 Wochen bezallt $72 \mathrm{t}-\mathrm{d}$ Latus 342 ta $7 \beta-\mathrm{d}$

Suma summarum aller vorgeschribner Ausgab Auf die Voyuoda vnd Ire vnntergegebnne häramia, Thuett dreü Tausent sehs hund[er]t dreüunndneünzig Phundt zweuundfinnffzig khreizer zwenn phening

Idest 3693 t $52 \mathrm{kr} 2 \mathrm{~d}(17)$

\section{Ausgab auff die Besazunngen}

No 60 Erstlichen herrn Cristoffen Vnngnaden freiherrn etc. Auf die Teüttschen vnnd winndischen khnecht des Geschloss Waraßdinni Inhalt des Musster Register vnnd seiner Quittung 2 Monet zallt $574 \mathrm{t}-\mathrm{d}$

No 61 Caspern Gottallen haubtman zu Sanndt Geörgen Auf seinem vnter-Burggraf vnnd 30 häramia Inhalt des Musster Register vnnd seiner Quittung 2 Monet zalt $207 \mathrm{t}-\mathrm{d}$

No 62 Item mer Ime sein haubtmans besoldung vnd Auf 22 Törshüzen vnd Wachter Inhalt des Musster Register vnnd seiner Quittunng 2 Monnett Zallt $212 \mathrm{t}-\mathrm{d}$

No 63 Item mer Ime auf 2 Sgartkhnecht Innhalt des Musster Register vnnd seiner Quittung 2 Monnet zalt $10 \mathrm{t}-\mathrm{d}$

No 64 Lasslo Rüttschaun haubtman zu Copreiniz sein haubtmans besoldung, Auf seinen Vnntter Burggraffen vnnd 30 Häramia daselbst Inhallt des Musster Register vnnd seiner Quittung 2 Monnet zallt $287 \mathrm{t}-\mathrm{d}$

Latus $1290 \mathrm{t}-\mathrm{d}(18)$

No 65 Item Ime Auf 12 Torschüzen vnnd wacht[er] Innhallt des Musster Regisster vnd seiner Quittung 2 Monnet zallt $72 \mathrm{t}-\mathrm{d}$

No 66 Jeörgen Strasser Haubtman zu Agram Auf Im vnnd seine vnntergebnen Teüttschen vnnd winndischen khnecht, Innhalt des Musster Regisster vnnd seiner Quittung 2 Monet zallt 842 t $15 \mathrm{kr}-\mathrm{d}$

No 67 Tomäsch Siberouitsch Voyuoda zu Chrastobiz Auf Im vnnd seine vnntergebnen Höramia Inhalt des Musster Register vnd seiner Quittung 2 Monet Zallt $195 \mathrm{t}-\mathrm{d}$ No 68 Niclas Husäritsch, Vouyuoda daselbs Auf Im vnnd seine vnntergebnen Häramia Inhalt des Musster Register vnnd seiner Quittung zalt 2 Monet 194 t - d 
No 69 Item Ime Auf 2 Sgart phärdt daselbst Innhalt des Musster Regisster vnnd seiner Quittung 2 Monet zallt $16 \mathrm{t}-\mathrm{d}$

No 70 Nicula Freilichobitsch vnnd Gregor Elssenägkh ped Rottmaister zu Grädisha, Inhalt des Muster Regisster vnnd seiner Quittung zalt 2 Monet $122 \mathrm{t}-\mathrm{d}$

Latus 1491 t $15 \mathrm{kr}-\mathrm{d}(19)$

No 71 Mattiäsch Müttschabitsch vnnd Jürgkho Copanitsch ped Rottmaiser zu Swinize, Innhalt des Musster Register vnd Irer Qüittüng bezallt $186 \mathrm{t}-\mathrm{d}$

No 72 Stüpann Dudolowitsch Auf die 2 Sgart Pfärdt daselbs, Innhallt des Musster Register vnnd seiner uüittüng 2 Monnet zallt $16 \mathrm{t}-\mathrm{d}$

No 73 Steffann Drägouanitsch, Rottmaister zu Prekhowörtschkhi, Innhallt des Musster Regisster vnnd seiner Quitung bezalt 2 Monnet $94 \mathrm{t}-\mathrm{d}$

No 74 Nicula Husäritsch, Auf Jurgkho od Jaßtrawarschkhi, Innhalt des Musster Regisster vnnd seiner Quittung 2 Monnet zallt $92 \mathrm{t}-\mathrm{d}$

No 75 Item Nicula Husäritsch Auf Pettern Mayritsch Rottmaister zu Widnize Innhalt des Musster Register vnnd seiner Quittung 2 Monnet zallt $62 \mathrm{t}-\mathrm{d}$

No 76 Mer Ime Nicula Husäritsch Auf Tomäsch khrobiz Rottmaister zu Liessniza Innhalt des Musster Register vnnd seiner Quittung 2 Monat zallt $62 \mathrm{t}-\mathrm{d}$

Latus $512 \mathrm{t}-\mathrm{d}(20)$

No 77 Blasy Smogoritsch Rottmaister zu Gomogoina Innhalt des Musster Register vnnd seiner Qüittüng 2 Monat zalt $62 \mathrm{t}-\mathrm{d}$

No 78 Mathiäsch Gerdäkhowitsch Rottmaister zu Petternia Inhalt des Musster Register vnnd seiner Quitung 2 Monnat zallt $62 \mathrm{t}-\mathrm{d}$

No 79 Nicula Husaritsch Auf die 2 Sgartt phärt zu Stäinischnigkh Innhalt des Musster register vnns seiner Quittung zalt 2 Monnett $16 \mathrm{t}-\mathrm{d}$

Latus $140 \mathrm{t}-\mathrm{d}$

Suma summarrum aler vorgeschribner Ausgab Auf die besazunngen, Thuet dreü Tausent vierhud[er]t dreiunddreissig Phundt Finnffzehen khreizer Idest 3433 t 15 k (21)

\section{Ausgab aüf die Püxenmaister}

No 80 Michel Paumgartner Pixenmaister zu Sanndt Geörgen Innhalt des Musster Register vnnd seiner Quittung Ił Monnet zallt $15 \mathrm{t}-\mathrm{d}$

No 81 Paullen Peödl pixenmaister zu sandt Geörgen, Innhalt des Musster Register vnnd seiner Quittung, zalt 2 Monet $20 \mathrm{t}-\mathrm{d}$

No 82 Jacaben Plochner Mussterschreiber Auf hannsen Mor vnnd Thoman Friess Ped Pixenmaister zu Copreiniz, Innhalt des Musster Register vnnd seiner Quittung bezalt 2 Monnet $44 \mathrm{t}-\mathrm{d}$

No 83 Hannsen Chrafft pixenmaister zu Chreüz Innhalt des Musster Register vnnd seiner Quittung 2 Monet zallt $20 \mathrm{t}-\mathrm{d}$

No 84 Bartlmee Weiss zeug wardt zu Warasnin, Innhalt des Musster Register vnd seiner zallt 2 Monet $24 \mathrm{t}-\mathrm{d}$

Latus $123 \mathrm{t}-\mathrm{d}(22)$

No 85 Hannsen Stainmez pixenmaister zu Warasin Innhalt des Musster Register vnnd seiner Quittung 2 Monnet bezollt $20 \mathrm{t}-\mathrm{d}$

No 86 Jeörg Rächigkh pixenmaister daselbst Innhallt des Musster Register vnnd seiner Quitung 2 Monet zalt $16 \mathrm{t}-\mathrm{d}$ 
No 87 Hannsens pücshaimer pixenmaister daselbs, Innhalt des Musster Register vnnd seiner Quittung 2 Monet zalt $16 \mathrm{t}-\mathrm{d}$

No 88 Banngräz posch pixenmaister daselbs Innhallt des Musster Register vnnd seiner Quittung 2 Monet zalt $16 \mathrm{t}-\mathrm{d}$

No 89 Jurco Chrainer püchsenmaister diennst geet an den ersten Nouember Monnetlichen, zalt Inhalt des Musster Register vnd seiner Quittung $8 \mathrm{t}-\mathrm{d}$

No 90 Hannsen schwertferber pixenmaister zu Chrastowiz zalt Innhalt seiner Quittung vnd des Musster Register 2 Monnet $16 \mathrm{t}-\mathrm{d}$

No 91 Luca $\beta$ Fux puchsenmaister zu Sissegg Inhalt des Musster Register vnnd seiner

Quittung 2 Monet zalt $16 \mathrm{t}-\mathrm{d}$

Latus $108 \mathrm{t}-\mathrm{d}(23)$

Suma summarrum aler Vorgeschribnner Ausgab Auf die Pixenmaister, Thuett, zwaihund[er]t

Ainunddreissig phundt phennig

Idest $231 \mathrm{t}-\mathrm{d}(24)$

\section{Steckhen khnecht}

No 92 Casparn Mlineritsch Stekhmaister, Auf Im vnd sein gesöllen, Innhalt des Muster

Register vnnd seiner Quittung 2 Monnatt zallt $36 \mathrm{t}-\mathrm{d}$

Allerlai Extraordinari auf Rattschleg vnd anders den khriegswesen Anhenngig, wie, volgtt

No 93 Erstlichen Iuraschinn Pribegen von wegen seiner Langwierigen gegebnen gehaimen khundtschafften, Aus verordung etc. khü. M. zu Behaim, Innhalt des herrn Obrissten Ausgang[nen] Rattschlag zuuerErung, bezalt 50 taler t[hue]t 58 t $20 \mathrm{kr}$ No 94 Herrn Cristoffen Vnngnaden, Inhalt seines von Ainer Ersamen Landtschafft Erlangten Rattschlag vnnd seiner Gegebnen Quittung, Auf seinen Burggraffen zu Warasin sein Ausstandige besoldung Auf 6 Monet bezalt $120 \mathrm{t}-\mathrm{d}$

Latus 178 t $20 \mathrm{kr}(25)$

No 95 Wallthausern Khazianner Auf Marttinn Jagetitsch vnnd Petter Gerbobiz Auf zerunng zu Ausbringung Etlicher häramia vnnd zu Erkhauffung Etlich[en] häramisch[en] Fenndlein Innhalt des herrn Obristen Rattschlag vnnd seiner gegebnen Quittung, zallt 8 t $30 \mathrm{k}$

Item mer Inne Khazianner, Auf Andre Säfferamitsch Burg(grafen) zu Agramb vnnd hannsenn Sprinnnger so Aus Beuelch des herrn Obrissten mit d(er) bezallung Auff Chrästouiz vnnd von Wegen Erkhundigung Etlicher Rottmaister gen Gomogoinna vnnd Petternia p(er) Innzicht geschikhtt zu zerunng geben, Innhalt Irer Quittunng $3 \mathrm{t} 30 \mathrm{kr}$

No 96 Vnnd dann Auf Anndree Spindler, so Ann Iezo das diennstvolgkh zu Chrästowiz Sissegg vnnd der Orten gemusstert Innhalt seiner Quittung Zerunng, Zallt 1 t.21 k, Thuen ped Possten Innhalt des herrn Obristen Rattschlag 4 t 51 k Latus 13 t $21 \mathrm{kr}(26)$

No 97 Seyfridt Närrnnig Innhalt Ainer Particular verzaichnus vnnd seiner Quittung bezallt auf fuer d[er] bezallunng $37 \mathrm{t} 10 \mathrm{kr}$ 
Suma der Extraordinari ausgab so dem khriegs wesen Anhenngig Thuet Zwaihund(er)t Achtundzwainzig phundt Ainundfinfzig khreizer Idest 228 t $51 \mathrm{k}(27)$

Summa summarum aller vorgeschribnner Ausgab auf vorbenante Zwai Monnet, Innhalt dises Particular Thuett Neünzehen Tausent Achthund[er]t vierundsechzig phundt Achtundzwainzig khreizer zwen phennig

Idest 19864 t 28 k 2 d (28)

Prilog 1. 2. Transkript drugog dokumenta krajiškog popisa za 1556. godinu

\section{Signatura}

Graz, Steiermärkisches Landesarchiv, Laa. A. Antiquum XIV, Sch. 22, 1556/4, 1556-X-29 Warasdin

Regesta

Popis vojske u Slavonskoj krajini 1556. godine

Copy

Austhaillung des Khriegßwesens An der Stayrerischen vnnd Winndischen Grännizen von Ersten Nouembris diss 56[ten] Jars

Dat[um] 29 Octobris 1556 (7)

Außthailung des Khriegsvolgs zw Roß vnnd Fueß An den Windischen Grannitzen vom Ersten Nouembris des 56[ten] Jars

Erstlichen von den 600 Gerussten Phärden zwen Fanen zw Wernsee vnnd Luettenwerg.

Mer zwen Fanen zw Ragkhaspurg.

Mer zwen Fanen aus Fürstenfeldt.

Item von den Geringen Phärden etc.

Herr Niclasen Grafen zw Seryn Waan phärd zw Tschorgouea 100

Sallay Chlement aus Brosentze phärdt 25

Herr Lucaß vnnd Herr Iacab Zäkhl Freyherrn zw khämär vnd derselben Enden In hungern phärdt 200

Zw Warasdin die Alt besatzung ph[ärdt] 32

Steffan Turotzi zw Ludperg phardt 20 (1)

Pekheri Janusch zw Rassing phardt 20

Herr Christoff vngnadt Freyh[err] phärdt 100 vnnd Iwan Margetitsch phardt 60 All zw Chopreinitz vnnd Lassla Rittschan haubtman dasselbst phardt 30, t[hue] t phardt 190

Item zw Sanndt Georgen Schloß Chasper Gottall haubtmann dasselbst phardt 30 vnd von Chopreinitz Noch Ain Anzall zu Ainer Sterkhung mit Abwechslung, Idest phardt 30

Herr Allapi Janusch phardt 60 Niclaß Wradätsch 60 herr Jobst Joseph von Thurn phardt 60 All zum Chreutz, t[hue]t phardt 180 
Herr Lasslo Kheretschin zw Cirkhwenä phardt 100

Hannsen Gessti zw loretschin phardt 60 (2)

Petter Radkhay zw Woschiacowina phärdt 50 vnnd dan Albeg 10 phärdt In den Khlosst[er] Iwanitsch Auff d[er] Schcart, Idest ph[ärdt] 60

Sallay Tomasch beim herrn Obrissten phardt 28

Ittem von härämiän, Erstlichen Janitscharn 50 zw Roß bey dem herrn Obrissten, Idest 50

Petter Sremetz Woywoda mit 28 haramiä zw Chopreinitz t[hue]t 28

Plauaz Margetitsch mit 50 haramiä zu Chopreynitz t[hue]t 50

Petter Khorontai mit 38 haramiä zu Sandt Jorgen Schloß t[hue]t 38

Räde Pribegg mit 48 haramiä zw Thopolouetz t[hue]t 48 (3)

Anndreasch Khopiar mit 26 haramia zu Cierkhuennä t[hue]t 26

Nadi Lasslo mit 33 haramiä zum Chreutz t[hue]t 33

Anthal Khopinskhi mit 38 häramiä, Auch zum Chreutz t[hue]t 38

Rädhko Pribegg mit 48 harämiä, Auch zum Chreutz t[hue]t 48

Petritsch Draskhouitsch mit 33 haramiä zw Grädetz t[hue]t 33

Thomasch Schandrowuetz mit 38 haramiä, Auch zu Gradetz t[hue]t 38

Jurkho Wöyoftschanin mit 37 haramiä zu Iwänitsch Im Chloster t[hue]t 37

Jorg Lettalä mit 42 haramiä zw Iwanitsch Im flegh[en] t[hue]t 42(4)

Iwan Nouagkh mit 48 harämia Auch zu Iwanitsch Im flegkhen t[hue]t 48

Jurco Schcotscheuitsch mit 28 haramiä zw Sissegkh t[hue]t 28

Jörg Khapa mit 31 haramiä Auch zw Sissegkh t[hue]t 31

Niclousch Khostkhouitsch mit 34 haramiä zw Wißwar t[hue]t 34

Thomasch Preskhotschilouitsch mit 40 haramiä zu Sigeth t[hue]t 40

Iwan Wellikhi mit 30 harämia, Auch zu Sigeth t[hue]t 30

Hassän Woywoda mit 49 haramiä, Auch zu Sigeth t[hue]t 49 (5)

Petter Khlutschär mit 49 harämiä, Auch zw Sigeth 49

Ittem Besazung Warasdin, Sanndt Jorgen Schloß, Chopreintz, Agram, Hrasstouiz vnnd die Andern flegkh[en] dasselbst gegen Chostainouitz, Posst phardt, Khuntschafftgelt, Extraordinari vnnd Paw Außgaben, Sambt dess herrn Obrisst[en] vnnd All Ander Offizier vnd Beuellchsleuth Außthaillung vnnd vnterhalttung Mog bey dem herrn Khriegszallmeister In dem Musster vnd zallregist[er]n Auch Chlerlich geschen werden

Dattum Warasdin den 29 Octobris A[nno] etc. Im 56. (6) 


\section{Prilog 2. Sistematizacija podataka iz dvaju transkribiranih popisa}

\section{Signatura}

Graz, Steiermärkisches Landesarchiv, Laa. A. Antiquum XIV, Sch. 22, 1556/4, 1556-X, sd. - 1556-XI-sd; 1556/4, 1556-X-29 Warasdin

Podaci iz drugog popisa upisani su kurzivom.

\begin{tabular}{|c|c|c|c|c|}
\hline \multicolumn{5}{|c|}{ 1. Slavonska krajina } \\
\hline \multicolumn{5}{|c|}{ 1. 1. ك̌tab } \\
\hline \multicolumn{2}{|c|}{ Rang, namjena } & \multicolumn{2}{|c|}{$\begin{array}{l}\text { Ime i prezime (poznate osobe ispisane su u } \\
\text { pravilnom obliku) }\end{array}$} & $\begin{array}{l}\text { Dvomjeseč- } \\
\text { ni iznos u } \\
\text { talirima }\end{array}$ \\
\hline \multicolumn{2}{|c|}{ Glavni zapovjednik Slavonske i Hrvatske krajine } & & Herr Hans Lenković & 800 \\
\hline \multicolumn{2}{|c|}{$\begin{array}{l}\text { Upravitelj ureda zamjenika glavnog zapovjed- } \\
\text { nika }\end{array}$} & \multicolumn{2}{|r|}{ Wallthauser von Wallterstain } & 80 \\
\hline \multicolumn{2}{|c|}{ Ratni savjetnik iz Koruške } & \multicolumn{2}{|c|}{$\begin{array}{l}\text { Herr Veit von Hallegg zu Ratzenegg (sa } 7 \\
\text { konja) }\end{array}$} & 212 \\
\hline \multicolumn{2}{|c|}{ Ratni savjetnik iz Kranjske } & \multicolumn{2}{|r|}{ Wallthauser Khazianner (s 8 konja) } & 228 \\
\hline \multicolumn{2}{|c|}{ Vojni blagajnik u Hrvatskoj i Slavonskoj krajini } & \multicolumn{2}{|r|}{ Georg Peögl (s 12 opremljenih konja) } & 292 \\
\hline \multicolumn{2}{|c|}{ Zapovjednik vojnog tajništva } & \multicolumn{2}{|r|}{ Daje se glavnom zapovjedniku } & 64 \\
\hline \multicolumn{2}{|c|}{ Popisivač (Musterschreiber) } & \multicolumn{2}{|r|}{ Jacob Plochnner } & 20 \\
\hline \multicolumn{2}{|c|}{ Glavni vojni trubač } & \multicolumn{2}{|r|}{ Hercälus Erd } & 32 \\
\hline \multicolumn{2}{|c|}{ Glavni vojni bubnjar } & \multicolumn{2}{|r|}{ Hanns } & 32 \\
\hline \multicolumn{4}{|c|}{ Ukupno 1. 1.} & 1760 \\
\hline \multicolumn{5}{|c|}{ 1. 2. Poštanski konji } \\
\hline \multicolumn{3}{|c|}{ Ime i prezime poštara } & \multirow{2}{*}{ Mjesto } & \multirow{2}{*}{$\begin{array}{l}\text { Dvomjesečni } \\
\text { iznos (taliri) }\end{array}$} \\
\hline U izvorniku & \multicolumn{2}{|l|}{ Prevedeno } & & \\
\hline Lucas Zellengge & & & Leoben & 20 \\
\hline Ischtuan Pridoieuitsch & \multicolumn{2}{|l|}{ Ištvan Pridojević } & Lendava & 20 \\
\hline Ianusch Gusmitsch & \multicolumn{2}{|l|}{ Ivan Kuzmić } & Varaždin & 48 \\
\hline Ibann Medagkh & \multicolumn{2}{|l|}{ Ivan Medak } & Lepoglava & 20 \\
\hline Michel Schischko & \multicolumn{2}{|l|}{ Mihovil Šiška } & Sveti Križ & 20 \\
\hline Larennz Cornnitschitsch & \multicolumn{2}{|l|}{ Lovro Karinčić } & Zagreb & 30 \\
\hline Michel Guettlich & Michael Gütlich & & Ptuj & 24 \\
\hline Bartlmee Fleischhagkher & Bartholomäus Fleischh & hacker & Maribor & 24 \\
\hline Paull Diuiagkh & Paul Divjak & & Landscha an der Mur & 40 \\
\hline Veytth Plaschg & & & Radkersburg & $\begin{array}{l}18(1,5 \text { mje- } \\
\text { seci) }\end{array}$ \\
\hline Janusch Mälikhozi & $\begin{array}{l}\text { Ivan Maliković (Ján } \\
\text { Malakóczi) }\end{array}$ & & Razkrižje & $\begin{array}{l}18(1,5 \text { mje- } \\
\text { seci) }\end{array}$ \\
\hline Petter Bambosch & Petar Bamboš & & Prelog & $\begin{array}{l}18(1,5 \mathrm{mje}- \\
\quad \text { seci })\end{array}$ \\
\hline Georg Tanngitsch & & & Letenye & $\begin{array}{l}15(1,5 \text { mje- } \\
\text { seci) }\end{array}$ \\
\hline & Ukupno 1. & & & 315 \\
\hline
\end{tabular}


P. Hegedić, M. Jurković, N. Ostojčić, F. Šimunjak - Popis isplata vojsci u Hrvatskoj i Slavonskoj...

\begin{tabular}{|c|c|c|c|c|}
\hline \multicolumn{3}{|c|}{$\begin{array}{l}\text { 1. 3. Obavještajci } \\
\text { Ukupno }\end{array}$} & & $\begin{array}{c}223 \text { talira i } 30 \\
\text { krajcara }\end{array}$ \\
\hline \multicolumn{5}{|c|}{ 1. 4. a Laka konjica } \\
\hline $\begin{array}{l}\text { Ime i prezime u } \\
\text { izvorniku }\end{array}$ & Prevedeno & Broj konjanika & $\begin{array}{l}\text { Mjesto (podaci iz } \\
\text { drugog popisa) }\end{array}$ & $\begin{array}{l}\text { Dvo- } \\
\text { mjeseč- } \\
\text { ni iznos } \\
\text { (taliri) }\end{array}$ \\
\hline $\begin{array}{l}\text { Herr Jacob Zägkhl na } \\
\text { ime oca }\end{array}$ & $\begin{array}{c}\text { Jakab Kövendi } \\
\text { Székely na ime oca } \\
\text { (Luka Zekel/Lukács } \\
\text { Kövendi Székely) }\end{array}$ & 100 & Körmend & 916 \\
\hline Herr Jacob Zägkhl & $\begin{array}{l}\text { Jakab Kövendi } \\
\text { Székely }\end{array}$ & 100 & Körmend & 916 \\
\hline $\begin{array}{l}\text { Herr Christoff Vngnad, } \\
\text { Freiherr }\end{array}$ & Christoph Ungnad & 100 & Koprivnica & 916 \\
\hline $\begin{array}{l}\text { Herr Niclas Graff zu } \\
\text { Serinn, Wann }\end{array}$ & Nikola Zrinski, ban & 100 & Csurgó & 916 \\
\hline $\begin{array}{l}\text { Petter Cästilampfi na } \\
\text { ime Herr Jobst Josepha } \\
\text { von Thurna }\end{array}$ & Petar Kaštelanović & 60 & Križevci & 538 \\
\hline Herr Hanns Allapi & Ivan Alapić & 60 & Križevci & 556 \\
\hline Herr Hanns Gessti & & 60 & Lovrenčina & 556 \\
\hline Niklas Bradatsch & Nikola Bradač & 60 & Križevci & 556 \\
\hline Petter Radtkay & Petar Rattkay & 60 & $\begin{array}{c}\text { Božjjakovina (50)/Klo- } \\
\text { štar Ivanić, izvidnica } \\
(10)\end{array}$ & 556 \\
\hline Ibänn Margettitsch & Ivan Margetić & 60 & Koprivnica & 556 \\
\hline Tomäsch Salbay & & 28 & $\begin{array}{l}\text { Kod glavnog zapo- } \\
\text { vjednika }\end{array}$ & 252 \\
\hline Lässlo Kherenntschini & $\begin{array}{l}\text { László Kerecsényi } \\
\text { (Kerečenji, de Ke- } \\
\text { rechen) }\end{array}$ & 100 & Cirkvena & 916 \\
\hline $\begin{array}{c}\text { Herr Lucas Zägkhl, } \\
\text { Freiherr zu Fridau, } \\
\text { umjesto Sallay Cle- } \\
\text { menta }\end{array}$ & $\begin{array}{l}\text { Luka Zekel/Lukács } \\
\text { Kövendi Székely }\end{array}$ & 25 & Berzence & 225 \\
\hline Steffann Turözi & & 20 & Ludbreg & 180 \\
\hline Janusch Pekheri & & 20 & Rasinja & 180 \\
\hline $\begin{array}{l}\text { Christoff Vnngnad, } \\
\text { Freyherr }\end{array}$ & Christoph Ungnad & 32 & Varaždin, stara posada & 288 \\
\hline $\begin{array}{l}\text { Casper Gottall, hau- } \\
\text { btman zu sant Geörgen }\end{array}$ & & 30 & $\begin{array}{l}\text { Đurđevac (i još uzeti } \\
30 \text { iz Koprivnice za } \\
\text { pojačanje) }\end{array}$ & 236 \\
\hline $\begin{array}{l}\text { Lässlo Rittschaun, hau- } \\
\text { btman zu Copreiniz }\end{array}$ & & 30 & Koprivnica & 240 \\
\hline $\begin{array}{l}\text { Kapetan Manngfredo } \\
\text { Manüago i zastavnik } \\
\text { konjičkih haramija } \\
\text { Janusch od Nemez }\end{array}$ & --- / Januš iz Nijemaca & & & 444 \\
\hline
\end{tabular}




\begin{tabular}{|c|c|c|c|c|}
\hline \multicolumn{4}{|c|}{ Ukupno 1.4.} & 9943 \\
\hline \multicolumn{5}{|c|}{ 1. 4. b. Teška (naoružana, oklopljena) konjica (prema drugom popisu) } \\
\hline & & & & \\
\hline 2 zastave & & 200 & $\begin{array}{c}\text { Veržej (Wernsee) i } \\
\text { Ljutomer }\end{array}$ & \\
\hline 2 zastave & & 200 & Radkersburg & \\
\hline 2 zastave & & 200 & Fürstenfeld & \\
\hline \multicolumn{2}{|c|}{ Ukupno 1. 4. b } & \multicolumn{2}{|c|}{600 konjanika } & \\
\hline \multicolumn{5}{|c|}{ 1.5. a. Haramije } \\
\hline \multicolumn{2}{|c|}{ Ime i prezime vojvoda } & \multirow[b]{2}{*}{ Broj haramija } & \multirow[b]{2}{*}{ Mjesto } & \multirow{2}{*}{$\begin{array}{c}\text { Dvomje- } \\
\text { sečni iznos } \\
\text { (taliri i } \\
\text { krajcari) }\end{array}$} \\
\hline U izvorniku & Prevedeno & & & \\
\hline Obrisst & Glavni zapovjednik & 50 janjičara na konju & & \\
\hline Lasslo Naig (Nadi Lasslo) & & 33 & Križevci & 190 \\
\hline $\begin{array}{l}\text { Jeörg Khappä (Jörg } \\
\text { Khapa) }\end{array}$ & & 31 & Sisak & 177 \\
\hline $\begin{array}{l}\text { Petter Sremäz (Petter } \\
\text { Sremetz) }\end{array}$ & Petar Sremac & 28 & Koprivnica & 177 \\
\hline $\begin{array}{c}\text { Rädtkho Prybeg (Rädhko } \\
\text { Pribegg) }\end{array}$ & Radko Pribeg & 48 & Križevci & 238 \\
\hline $\begin{array}{l}\text { Plauez Margetitsch (Pla- } \\
\text { uaz Margetitsch) }\end{array}$ & Plavac Margetić & 50 & Koprivnica & 283 \\
\hline $\begin{array}{c}\text { Petter Chorannthey (Petter } \\
\text { Khorontai) }\end{array}$ & & 38 & Đurđevac & 213 \\
\hline $\begin{array}{l}\text { Annthall Copinnsskhi } \\
\text { (Anthal Khopinskhi) }\end{array}$ & Antol Kopinski & 38 & Križevci & 254 \\
\hline $\begin{array}{c}\text { Petter Traschkowitsch } \\
\text { (Pettritsch Draskhouitsch) }\end{array}$ & Petrić Drašković & 33 & Gradac & 187 \\
\hline $\begin{array}{l}\text { Jurgkho Woiaffzänn } \\
\text { (Jurkho Wöyftschanin) }\end{array}$ & & 37 & Kloštar Ivanić & 245 \\
\hline $\begin{array}{l}\text { Jeörg Lettella (Jorg } \\
\text { Lettalä) }\end{array}$ & Georg Lettella & 42 & Ivanić & 281 \\
\hline $\begin{array}{l}\text { Ibann Nouägkh (Iwan } \\
\text { Nouagkh) }\end{array}$ & Ivan Novak & 48 & Ivanić & 306 \\
\hline $\begin{array}{l}\text { Räde Prybeg (Räde } \\
\text { Pribegg) }\end{array}$ & Rade Pribeg & 48 & Topolovac & 273 \\
\hline $\begin{array}{c}\text { Tomash od Schanndrofza } \\
\text { (Thomasch } \\
\text { Schandrowuetz) }\end{array}$ & $\begin{array}{l}\text { Tomaš od Šan- } \\
\text { drovca }\end{array}$ & 38 & Gradac & 213 \\
\hline $\begin{array}{l}\text { Jurgkho Sgottschewitsch } \\
\text { (Jurco Schcoscheuitsch) }\end{array}$ & Jurko Skošević & 28 & Sisak & 157 \\
\hline $\begin{array}{c}\text { Anndreas Copiär (Anndre- } \\
\text { asch Khopiar) }\end{array}$ & Andraš Kopjar & 26 & Cirkvena & 157 \\
\hline
\end{tabular}


P. Hegedić, M. Jurković, N. Ostojčić, F. Šimunjak - Popis isplata vojsci u Hrvatskoj i Slavonskoj...

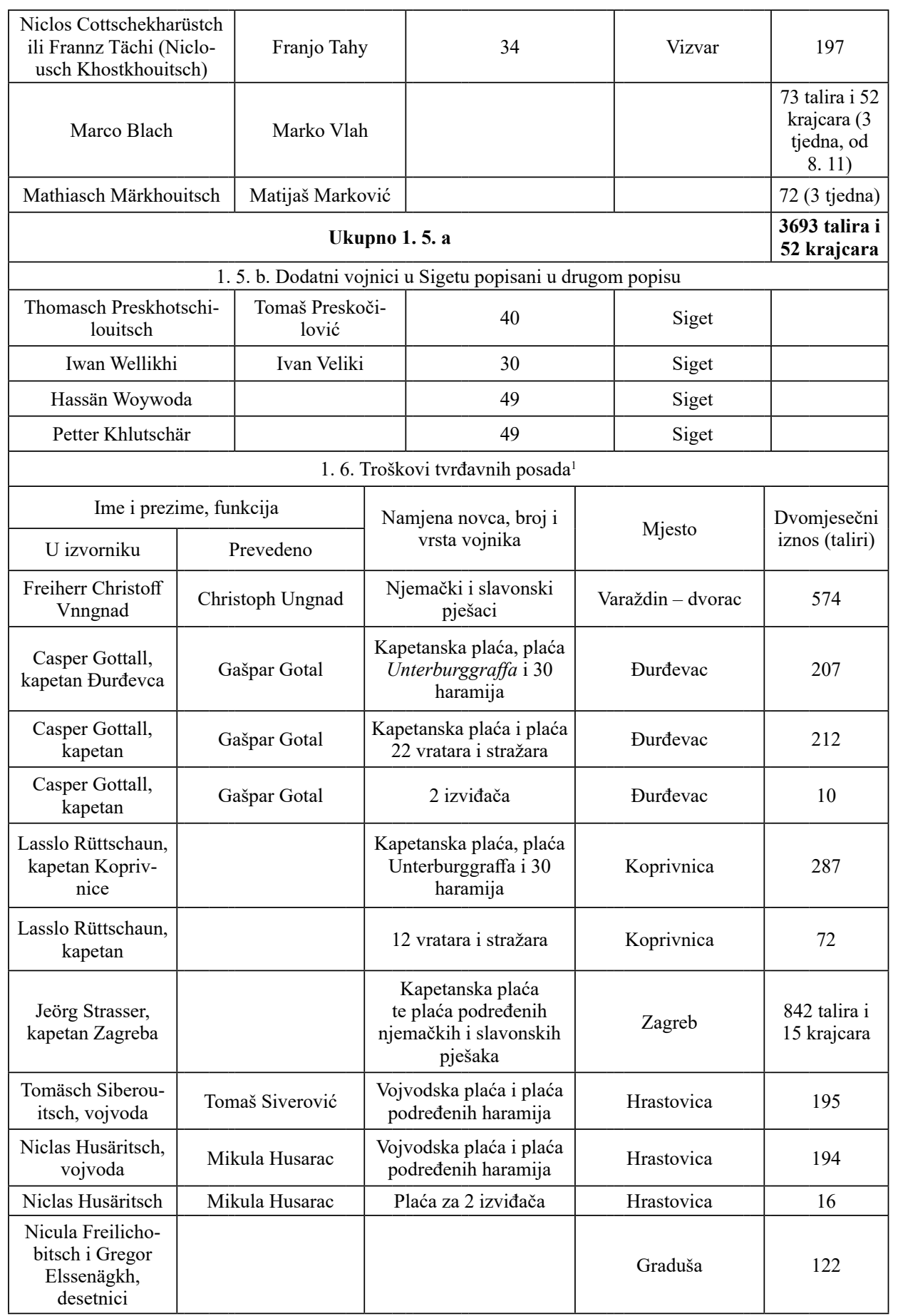

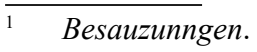




\begin{tabular}{|c|c|c|c|c|}
\hline $\begin{array}{l}\text { Mattiäsch } \\
\text { Müttschabitsch i } \\
\text { Jürgkho Copa- } \\
\text { nitsch, desetnici }\end{array}$ & & & Svinica & 186 \\
\hline $\begin{array}{l}\text { Stüpann Dudo- } \\
\text { lowitsch }\end{array}$ & & Plaća za 2 izviđača & Svinica (?) & 16 \\
\hline $\begin{array}{l}\text { Steffann Drägoua- } \\
\text { nitsch, desetnik }\end{array}$ & & & Prevršac & 94 \\
\hline $\begin{array}{c}\text { Jurgkho od } \\
\text { Jasstawarschki } \\
\text { na ime Mikule } \\
\text { Husarca }\end{array}$ & $\begin{array}{l}\text { Jurko iz Jastrebar- } \\
\text { skog }\end{array}$ & & Jastrebarsko & 92 \\
\hline $\begin{array}{l}\text { Petter Mayritsch, } \\
\text { desetnik, na ime } \\
\text { Mikule Husarca }\end{array}$ & & & Widnica & 62 \\
\hline $\begin{array}{l}\text { Tomäsch Khrobiz, } \\
\text { desetnik, na ime } \\
\text { Mikule Husarca }\end{array}$ & & & Liješnica & 62 \\
\hline $\begin{array}{l}\text { Blasy Smogo- } \\
\text { ritsch, desetnik }\end{array}$ & & & Komogovina & 62 \\
\hline $\begin{array}{l}\text { Mathiäsch } \\
\text { Gerdäkhowitsch, } \\
\text { desetnik }\end{array}$ & & & $\begin{array}{l}\text { Petternia (Jabukovac } \\
\text { (?)) }\end{array}$ & 62 \\
\hline $\begin{array}{l}\text { Nicula Husaritsch, } \\
\text { u ime } 2 \text { izviđača }\end{array}$ & Mikula Husarac & & Steničnjak & 16 \\
\hline \multicolumn{4}{|c|}{ Ukupno 1.6.} & $\begin{array}{l}3433 \text { talira i } \\
15 \text { krajcara }\end{array}$ \\
\hline \multicolumn{5}{|c|}{ 1. 7. Puškari } \\
\hline \multicolumn{3}{|c|}{ Ime i prezime } & Mjesto & $\begin{array}{l}\text { Dvomjesečni } \\
\text { iznos (taliri) }\end{array}$ \\
\hline \multicolumn{3}{|c|}{ Michel Paumgartner } & Đurđevac & 30 (1,5 mjeseci) \\
\hline \multicolumn{3}{|c|}{ Paul Peödl } & Đurđevac & 20 \\
\hline \multicolumn{3}{|c|}{$\begin{array}{c}\text { Hanns Mor i Thoma Friess, uime Jacoba Plochnera, } \\
\text { musterschreibera }\end{array}$} & Koprivnica & 44 \\
\hline \multicolumn{3}{|c|}{ Hanss Chrafft } & Križevci & 20 \\
\hline \multicolumn{3}{|c|}{ Bartlmee Weiss, oružar } & Varaždin & 24 \\
\hline \multicolumn{3}{|c|}{ Hanns Stainmez } & Varaždin & 20 \\
\hline \multicolumn{3}{|c|}{ Jeörg Rächigkh } & Varaždin & 16 \\
\hline \multicolumn{3}{|c|}{ Hanns Pücshaimer } & Varaždin & 16 \\
\hline \multicolumn{3}{|c|}{ Banngräz Posch } & Varaždin & 16 \\
\hline \multicolumn{3}{|c|}{ Jurco Chrainer } & Varaždin & $\begin{array}{l}8 \text { (samo stu- } \\
\text { deni) }\end{array}$ \\
\hline \multicolumn{3}{|c|}{ Hanns Schwertferber } & Hrastovica & 16 \\
\hline \multicolumn{3}{|c|}{ Lucaß Fux } & Sisak & 16 \\
\hline \multicolumn{4}{|c|}{ Ukupno 1.7.} & 231 \\
\hline \multicolumn{5}{|c|}{ 1. 8. Tamničari } \\
\hline \multicolumn{4}{|c|}{ Caspar Mlineritsch, majstor tamničar, osobna i plaća pomoćnika } & 36 \\
\hline \multicolumn{4}{|c|}{ Ukupno 1.8.} & 36 \\
\hline
\end{tabular}


P. Hegedić, M. Jurković, N. Ostojčić, F. Šimunjak - Popis isplata vojsci u Hrvatskoj i Slavonskoj...

\begin{tabular}{|c|c|c|}
\hline \multicolumn{3}{|c|}{ 1. 9. Dodatni troškovi } \\
\hline Iuraschinn Pribeg & $\begin{array}{c}\text { Naknada za tajne dojave, iz troškova za savjeto- } \\
\text { vanje glavnog zapovjednika }(50 \mathrm{t})\end{array}$ & $\begin{array}{l}58 \text { talira i } 20 \\
\text { krajcara }\end{array}$ \\
\hline Herr Cristoff Vnngnad & $\begin{array}{c}\text { Christoph Ungnad, za savjet i plaću Burggraffa } \\
\text { Varaždina }\end{array}$ & $\begin{array}{c}120 \text { talira za } 6 \\
\text { mjeseci }\end{array}$ \\
\hline $\begin{array}{l}\text { Wallthauser Khazianner, Marttinn Jage- } \\
\text { titsch, Petter Gerbobiz }\end{array}$ & $\begin{array}{c}\text { Za uzdržavanje i dovođenje nekoliko haramija i } \\
\text { kupovinu haramijskih zastava }\end{array}$ & $\begin{array}{l}8 \text { talira i } 30 \\
\text { krajcara }\end{array}$ \\
\hline $\begin{array}{l}\text { Wallthauser Khazianner, Andre Saffe- } \\
\text { ramitsch Burggraff iz Zagreba, Hanns } \\
\text { Sprinnger }\end{array}$ & $\begin{array}{c}\text { Putni troškovi za odnošenje plaća u Hrastovicu } \\
\text { prema nalogu zapovjednika te za odlazak u } \\
\text { Komogovinu i Petterniu radi ispitivanja nekih } \\
\text { desetnika }\end{array}$ & $\begin{array}{l}3 \text { talira i } 30 \\
\text { krajcara }\end{array}$ \\
\hline Anndree Spindler & $\begin{array}{c}\text { Za muštranje vojske u Hrastovici, Sisku i obli- } \\
\text { žnjim mjestima }\end{array}$ & $\begin{array}{l}4 \text { talira } 51 \\
\text { krajcar }\end{array}$ \\
\hline Seyfridt Närnning & Prema posebnom popisu, plaća za prijevoz & $\begin{array}{l}37 \text { talira i } 10 \\
\text { krajcara }\end{array}$ \\
\hline \multicolumn{2}{|c|}{ Ukupno 1.9.} & $\begin{array}{l}228 \text { talira i } 51 \\
\text { krajcar }\end{array}$ \\
\hline \multicolumn{2}{|c|}{ UKUPNO SVE } & $\begin{array}{l}19864 \text { talira } \\
28 \text { krajcara i } 2 \\
\text { denara }\end{array}$ \\
\hline
\end{tabular}

\section{Prilog 3. Kratki životopisi krajiških službenika}

Alapić (Alapy, Alaphy), Ivan iz Velikog Kalnika (mađ. Nagykemlek), pripadnik ugarske plemićke obitelji nastanjene u Hrvatskoj od 15. stoljeća. Bio konjički kapetan u Križevcima, istaknuo se u bitkama 1542. kod Pešte, 1553. kod Velikoga Kalnika, 1557. u bici kod Sv. Jelene blizu Rakovca, 1558. pod Vinodolom i 1565. kod Obreške. Godine 1555. dobio titulu baruna, a 1560. imenovan privremenim slavonskim glavnim kapetanom. Umro 11. rujna 1567.

Bradač, Nikola, pripadnik plemićke obitelji Bradač s pridjevkom iz Ladomerca. Hrvatski biografski leksikon donosi vijest da je bio djelatan u Vojnoj krajini između 1552. i 1555., stoga nije nerazumno pretpostaviti da je u obrađenom popisu iz 1556. riječ o istoj osobi. Godine rođenja i smrti nepoznate.

Gotal, Gašpar (Caspar), pripadnik plemićke obitelji Gotal u Varaždinskoj županiji. Od 1543. do 1560. godine bio vlasnik Gotalovca, Završja i Vinice kraj Varaždina, a u Moravču posjedâ Bedenice i Šimunovca. Bio blagajnik pri utvrđivanju Zagreba i Siska 1552./1553. godine. U popisu iz 1556. spomenut kao kapetan Đurđevca. Godine rođenja i smrti nisu poznate, obitelj izumrla u 18. stoljeću.

Katzianer (Kacijaner), Baltazar, sin Ivana Katzianera. Uz Erazma Obrićana, kranjski staleži imenovali ga 1542. godine ratnim savjetnikom - čin pod kojim ga spominje obrađeni popis iz 1556. Prisustvovao oslobođenju Beča 1583. godine. Godine rođenja i smrti nisu poznate. 
Kaštelanović, Petar stariji, rođen oko 1526., sin Ivana Kaštelanovića, kraljevskog blagajnika i kraljevinskog kapetana, te Barbare Ösi. Kralj Maksimilijan dodijelio mu barunat 1569. Iako ni u jednom službenom dokumentu nije označen kao kraljevski kapetan, tako ga oslovljava Franjo Tahy u pismu iz 1569. Prvom suprugom bila mu je Ana Bradač, kći Mirka Bradača, a drugom Ana Vesej. Umro 1570. ili 1571.

Keglević, Petar II. iz Bužina, hrvatski plemić rođen oko 1500. Istaknuo se u bici kod Jajca, od 1521. do 1522. jajački ban, a od 1522. do 1526. i kapetan konjaništva Jajca. Od 1530. do 1540. veliki župan varaždinski, od 1534. upravitelj opatije u Topuskom, a od 1533. do 1537. kraljevski povjerenik za Hrvatsku. Godine 1535. postao kapetan utvrde Bihać, pod svoje zapovjedništvo stavio i okolne utvrde na južnoj crti obrane. Od 1537. do 1541. hrvatsko-slavonski ban (do 1539. uz Tomu Nadasdyja). Uzaludno se trudio od kralja dobiti novčanu i vojnu pomoć za spašavanje i gradnju utvrda. Nakon gubitka obiteljskih posjeda kupio Kostel i Krapinu te zauzeo Čakovec protiv kraljeve volje (sukobi s Imreffyjima i Székelyima, kao i s krunom). Umro 1554. ili 1555.

Kérecsenyi (Kerencheni), Ladislav iz Kanyafolda, konjički kapetan u Slavonskoj krajini, od 1554. do 1556. sigetski kapetan, a od 1561. do 1566. kapetan Gyule. Oženio se s Katarinom Orlovčić i tako došao u posjed Sokolca koji su, zbog strateške važnosti, kraljevske vlasti privremeno preuzele i pridružile Bihaćkoj kapetaniji. U njegovu posjedu bio i Vinodol. U vlasništvu braće Kérecsenyi bila i utvrda u Cirkveni. Umro 1566.

Lenković, Ivan, hrvatski plemić. Sudjelovao u obrani Beča (1529), od 1530. vjerojatno zapovjednik konjaništva kranjskih državnih staleža. Od 1537. dozapovjednik Bihaćke kapetanije, od 1546. zapovjednik sveukupnih uskočkih postrojbi. Bio zamjenik vrhovnoga kapetana Hrvatske i Slavonske krajine od 1547. do 1556. Prema kraljevskom nalogu, 1553. izradio nacrt obrane hrvatsko-slavonskih granica. Sudjelovao u obrani Sigeta za prve opsade (1556). Podignuo Podbrežje (1557) i tvrđavu Nehaj (1558), obnovio utvrdu Senja. Od 1556. vrhovni kapetan Hrvatske i Slavonske krajine, s položaja kapetana zbog bolesti se povukao iduće godine. Umro 1569.

Pravoslavna obitelj Margetić na prostor Kraljevine Slavonije najvjerojatnije se doselila između 1542. i 1551., predvođena vojvodom Ivanom Margetićem (Rascianus), koji je zapovijedao s 49 konjanika. Isti Ivan Margetić (Ibänn Margettitsch) spomenut u popisu iz 1556. godine kao zapovjednik lake konjice u Koprivnici, ravnao šezdesetoricom konjanika. U popisu iz 1577. ponovno uvršten među značajnije vojskovođe. Njegov brat, Plavac Margetić, bio je harambaša. Prema popisu iz 1556., pod svojim zapovjedništvom u Koprivnici imao pedesetoricu haramija. Tri godine kasnije (1559) postao zapovjednikom lake konjice, i dalje u Koprivnici, ravnajući šezdesetoricom konjanika. Kralj Ferdinand III. 1646. obitelji dao plemićku povelju. 
Pögl, Georg, rođen oko 1526., drugi sin Sebalda Pögla, štajerskog majstora kovača i proizvođača oružja koji je nosio titulu Freiherr von Reifenstein [und Arberg], i Cordule von Herberstein. Vjerojatno sveučilišno obrazovan, oženio se s Helenom, kćeri Luke Székelyja. Preminuo 11. ožujka 1557. Loza po muškoj liniji izumrla u 16. stoljeću.

Ráttkay (Ratkaj), Petar II. iz Velikog Tabora (mađ. Nagytabor), pripadnik hrvatske magnatske obitelji ugarskog podrijetla. Bio izaslanik zagrebačkog kaptola, 1559. Ferdinand I. Habsburški dodijelio mu barunat, a Rudolf II. Habsburški potvrdio mu plemstvo i grb 1578. u znak zahvale za službu u Vojnoj krajini. Pradjed hrvatskog povjesničara Jurja Ratkaja. Umro 1586.

Székely (Zekel, Zäckl, Sekelj), Jakov, rođen 1530., sin Luke Székelyja. Bio zapovjednik nad konjaništvom u utvrdi Đurđevac, a zajedno s Veitom von Halleggom poslanik hrvatskih sabornika nadvojvodi Karlu u Sabor u Varaždinu 1578. Prvom mu je suprugom bila Sofija von Herberstein, a drugom Margareta Erdődy. Umro 1583.

Székely (Zekel, Zäckl, Sekelj), Luka iz Kövenda, pripadnik hrvatske plemićke obitelji podrijetlom iz Erdelja, barun Ormošda, od 1544. kapetan Đurđevca, Prodavića i Koprivnice. Bio predstojnik slavonske tridesetnice te tako i član kraljevskog povjerenstva za obnovu zagrebačkih utvrda, uz to kapetan kraljevske vojske u Slavoniji, hrvatski ban, a od 1567. do 1568. i glavni kapetan Hrvatsko-slavonske krajine. Godine 1536. oženio se s Katarinom Imreffy te tako stekao Kostel i polovinu posjeda Krapine (sporovi s obitelji Keglević). Umro 1568.

Ungnad, Kristofor (Krsto) iz Sonnegga, sin Ivana Ungnada. Bio varaždinski župan i kapetan varaždinske tvrđave. U njegovu posjedu bili su i Samobor te utvrda u Drnju koja se nalazila pod koprivničkim kapetanom. Zapovjednik pokretnog konjaništva na slavonskoj granici (uz Tomu Salaja), već 1557. istaknuo se porazivši pod Koprivnicom osmansku akindžijsku postrojbu. Bio vrhovni egerski kapetan, a od 1578. do 1583. i hrvatsko-slavonski ban. Bio u sukobu s najmoćnijim plemićkim obiteljima u Kraljevstvu pa se uglavnom oslanjao na potporu srednjeg i nižeg plemstva.

von Hallegg zu Ratzenegg, Veit iz mjesta Hallegg kod Ratzenegga, koruški plemić, rođen 1527., podrijetlom iz vojne obitelji. Od 1554. do 1558. godine zapovjednik izravno podređen Ivanu Lenkoviću, glavnom zapovjedniku Hrvatske i Slavonske krajine. Od 1559. do 1568. zamjenik zapovjednika Slavonske krajine, a od 1568. pa do 1589. godine glavni zapovjednik Slavonske krajine. Sjedište mu je bilo u Varaždinu. Umro 15. travnja 1589.

von Wallterstein, Wallthausern, najvjerojatnije pripadnik plemićke i grofovske obitelji Walderstein/Walterstein (nema pouzdanih podataka). Obitelj, inače njemačkog podrijetla, 1494. godine od cara Maksimilijana Habsburškog u posjed dobila feud Račice u Istri. 
Zrinski, Nikola IV., hrvatski plemić. Sudjelovao u opsadi Beča (1529), 1539. dao pogubiti Ivana Katzianera. Ženio se dvaput, prvi put s Katarinom Frankapan (time sklopio baštinski ugovor s ozaljskom granom Frankapana), a drugi put s Evom von Rosenberg. Od 1542. do 1556. bio hrvatskim banom. Za primirja 1554. na dvoboj izazvao bosanskog pašu Muhameda. Branio Siget za prve opsade (1556), 1557. postao kraljevskim tavernikom. Bio kapetan Sigeta (1561. - 1566) i zapovjednik Prekodunavske granice (1563. - 1566). Poginuo braneći Siget 1566.

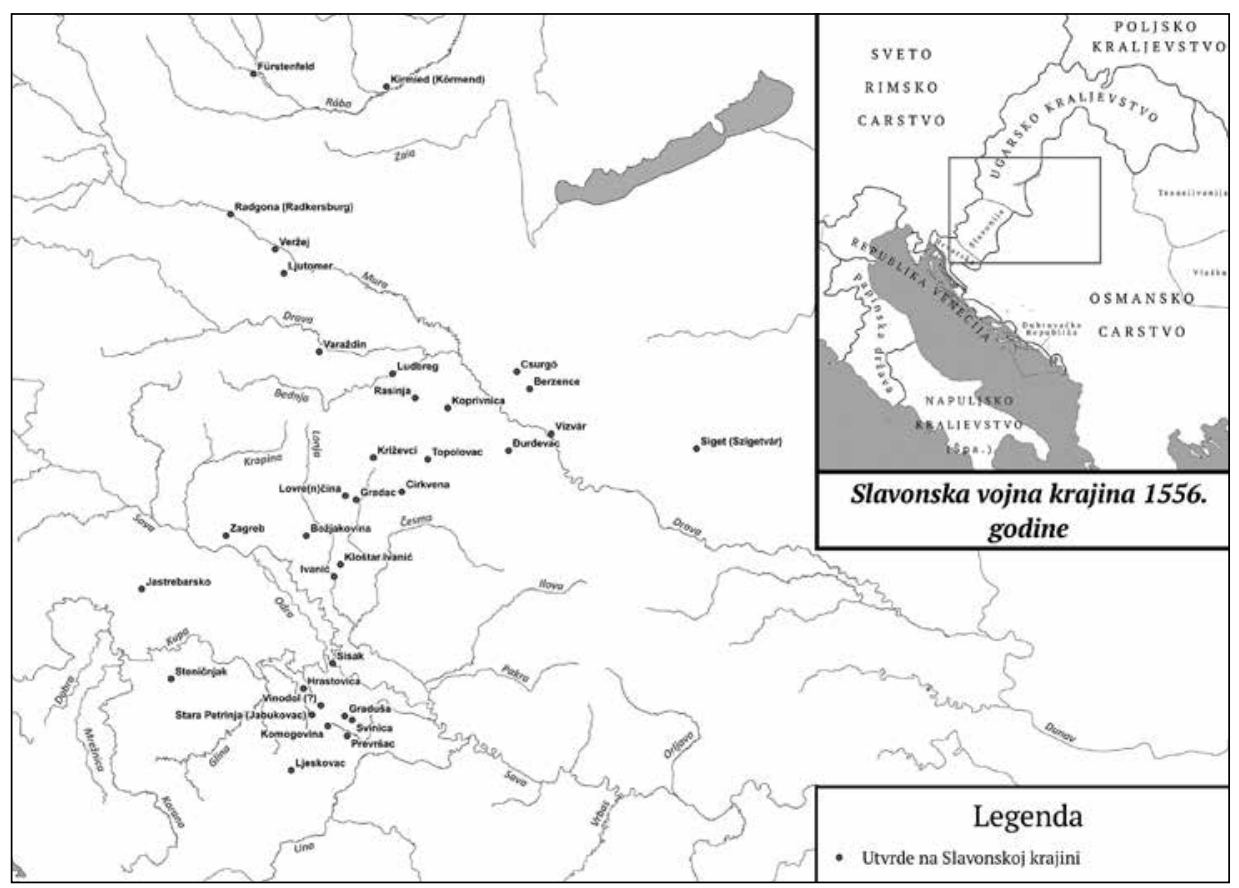

Slika 1: Karta krajiških utvrda Slavonske krajine 1556. godine ${ }^{28}$

$\overline{28}$ Karta utvrda. Izradili Filip Šimunjak i Petar Hegedić na temelju obrađenih popisa. Za političku kartu 1556. godine korišteno: http://www.ieg-maps.de/mapsp/mappEu555_Serie2.htm (posjet 21. 10. 2019). 


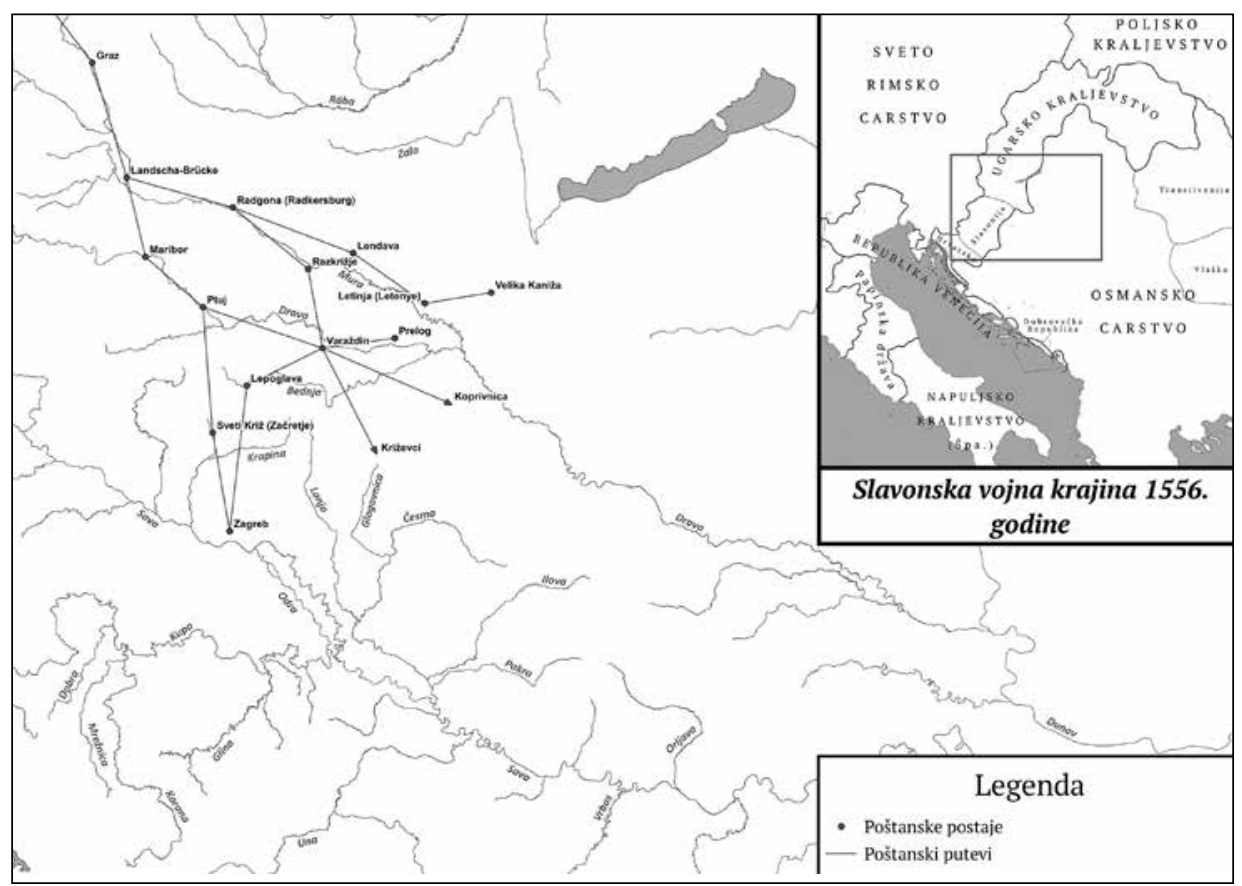

Slika 2: Karta krajiške pošte u Slavonskoj krajini 1556. godine ${ }^{29}$

$\overline{29}$ Karta pošte. Izradili Filip Šimunjak i Petar Hegedić na temelju obrađenih popisa. Poštanska veza prema Velikoj Kaniži ne spominje se u krajiškom popisu, no dokaze o njezinu postojanju pronašao je Andrej Hozjan (kralj Ferdinand bio je prisutan tih mjeseci u zaleđu sukoba, a u listopadu boravio je i u samoj Kaniži te je svakako htio imati dobre poštanske veze do bečkog dvora pa i do Požuna, usp. Hozjan 2017: 53). Na popisu ne spominje se niti poštanska linija prema Sigetu, za koju znamo da je sigurno postojala nekoliko godina kasnije, no za sada nemamo čvrstih dokaza da je linija postojala 1556. godine te stoga nije ucrtana. Za političku kartu 1556. godine korišteno: http://www.ieg-maps.de/mapsp/mappEu555_Serie2.htm (posjet 21. 10. 2019). 


\section{Bibliografija}

\section{Arhivski izvori}

Graz, Steiermärkisches Landesarchiv

Laa. A. Antiquum XIV, Sch. 22, 1556/4, 1556-X, sd. - 1556-XI-sd

Laa. A. Antiquum XIV, Sch. 22, 1556/4, 1556-X-29 Warasdin

Laa A. Antiquum XIV Militaria, 1577-VIII-24-Warasdin

\section{Izvori i literatura}

BEDENKO, Vladimir. 1993. Urbanistički razvoj Križevaca do sredine 19. stoljeća. U Križevci: grad i okolica, ur. Anđelko Badurina, Žarko Domljan, Miljenka Fischer, Katarina Horvat-Levaj, 73-92. Zagreb: Institut za povijest umjetnosti Sveučilišta u Zagrebu.

BOJNIČIĆ, Ivan. 1899. Der Adel von Kroatien und Slavonien, sv. 4: J. Siebmacher's grosses und allgemeines Wappenbuch. Nürnberg: Bauer \& Raspe.

COFEK, Danijela, Nataša ŠTEFANEC. 2011. Vojnokrajiške institucije u praksi: Slavonska krajina 1578. godine. Podravina 10/19: 5-44.

HOZJAN, Andrej (ur). 2002. Pošta sjeverozapadne Hrvatske. Zagreb - Varaždin: Hrvatske pošte, Hrvatska akademija znanosti i umjetnosti.

HOZJAN, Andrej. 2009. Varaždinska vojnopoštna postaja in poštarji v 16. stoletju. U 800 godina slobodnog kraljevskog grada Varaždina: 1209. - 2009., ur. Miroslav Šicel, Slobodan Kaštela, 263-276. Varaždin: Hrvatska akademija znanosti i umjetnosti - Zavod za znanstveni rad, Grad Varaždin, Varaždinska županija.

HOZJAN, Andrej. 2010. Lukas Székely/Zekel de Kövend, Freiherr von Friedau, 15001574/1575. Rutengänge, Studien zur geschichtlichen Landeskunde 54: 153-168.

HOZJAN, Andrej. 2017. Prve pošte i poštari kontinentalne Hrvatske. Postanak i djelatnost vojnokrajiškog poštanskog sustava na području između Kupe i Mure do 1606. godine. Varaždin - Zagreb - Maribor: Hrvatska akademija znanosti i umjetnosti - Zavod za znanstveni rad, Filozofski fakultet - Centar za komparativnohistorijske i interkulturne studije, Univerza v Mariboru - Filozofska fakulteta.

JURKOVIĆ, Ivan. 2003. Klasifikacija hrvatskih raseljenika za trajanja osmanske ugroze (od 1463. do 1593). Migracijske i etničke teme 19/2-3: 147-174.

JURKOVIĆ, Ivan. 2004. The Fate of the Croatian Noble Families in the Face of Ottoman Advance. Ph.D. diss., Central European University.

KASER, Karl. 1997. Slobodan seljak i vojnik: povojačenje agrarnog društva u Hrvatskoslavonskoj Vojnoj krajini (1535-1881), sv. 1-2. Preveo Josip Brkić. Zagreb: Naprijed.

KRUHEK, Milan. 1995. Krajiške utvrde i obrana Hrvatskog Kraljevstva tijekom 16. stoljeća. Zagreb: Institut za suvremenu povijest.

LASZOWSKI, Emilij. 1923. Gorski kotar i Vinodol-dio državine knezova Frankopana i Zrinskih: mjestopisne i povjesne crtice. Zagreb: Matica hrvatska.

LAZANIN, Sanja. 2004. Priručnik iz njemačke paleografije. Zagreb: TIPEX. 
P. Hegedić, M. Jurković, N. Ostojčić, F. Šimunjak - Popis isplata vojsci u Hrvatskoj i Slavonskoj...

LAZANIN, Sanja, Nataša ŠTEFANEC. 2000. Habsburg Military Conscription and Changing Realities of the Triplex Confinium (16 $6^{\text {th }}-18^{\text {th }}$ Centuries). U Constructing Border Societies on the Triplex Confinium, ur. Drago Roksandić, Nataša Štefanec, 91-116. Budimpešta: Central European University.

LOPAŠIĆ, Radoslav. 1884. Spomenici hrvatske Krajine, knj. 1.: Od godine 1409. do 1610. Zagreb: Academia scientiarum et artium Slavorum meridionalium.

LOPAŠIĆ, Radoslav. 1885. Prilozi za poviest Hrvatske XVI. i XVII. vieka iz štajerskoga zemaljskoga arhiva u Gradcu. Starine JAZU XVII: 151-232.

LOPAŠIĆ, Radoslav. 1887. Prilozi za poviest Hrvatske iz XVI. i XVII. vieka iz štajerskog zemaljskog arhiva u Gradcu. Starine JAZU XIX: 1-80.

LOPAŠIĆ, Radoslav. 1890. Bihać i Bihaćka krajina: mjestopisne i poviestne crtice: sa jednom zemljopisnom kartom i sa četrnaest slika. Zagreb: Matica hrvatska.

LOPAŠIĆ, Radoslav. 1895. Oko Kupe i Korane-mjestopisne i povjestne crtice: sa dvadeset $i$ tri slike i jednom zemljopisnom kartom. Zagreb: Matica hrvatska.

MAČEK, Pavao, Ivan JURKOVIĆ. 2009. Rodoslov plemića i baruna Kaštelanovića od Svetog Duha (od 14. do 17. stoljeća). Slavonski Brod: Hrvatski institut za povijest Podružnica za povijest Slavonije, Srijema i Baranje.

MESIĆ, Matija. 1866. Život Nikole Zrinjskoga, sigetskoga junaka. Zagreb: Matica ilirska.

PÁLFFY, Géza. 1995. A Magyarországi és délvidéki végvárrendszer 1576. és 1582. évi jegyzékei. Hadtörténelmy Közlemények 1: 114-185.

PÁLFFY, Géza. 1997. Kerületi és végvidéki főkapitányok ésfőkapitany-helyettesek Magyarországon a 16-17. században. Történelmi szemle 2: 257-287.

PÁLFFY, Géza. 1999. A bécsi udvar és a magyar rendek a 16. században. Történelmi Szemle 3-4: 331-367.

PÁLFFY, Géza. 2001. A törökellenes határvédelmi rendszer fenntartásának költségei a 16. század második felében. Studia Agriensia 22: 183-220.

PÁLFFY, Géza. 2002. Die Türkenabwehr in Ungarn im 16. und 17. Jahrhundert - ein Forschungsdesiderat. Anzeiger der philosophisch-historischen Klasse 137: 99-131.

PÁLFFY, Géza. 2003a. A Bajcsavárig vezető út: A Stájer rendek részvétele a dél-dunántúl Törökellenes határvédelmében a XVI. Században. Különlenyomat a hadtörténelmi közlemények 116: 463-504.

PÁLFFY, Géza. 2003b. Türkenabwehr, Grenzsoldatentum und die Militarisierung der Gesellschaft in Ungarn in der Frühen Neuzeit. Historisches Jahrbuch 123: 111-148.

PÁLFFY, Géza. 2004. Kriegswirtschaftliche Beziehungen zwischen der Habsburgermonarchie und der ungarischen Grenze gegen die Osmanen in der zweiten Hälfte des 16. Jahrhunderts: Unter besonderer Berücksichtigung des königlihen Zeughauses in Kaschau. Ungarn Jahrbuch: Zeitschrift für interdisziplinäre Hungarologie 27: 17-40.

PETRIĆ, Hrvoje. 2016. Iz najstarije povijesti Srba u Podravini. Podravina 15/30: 199-212.

SIMONITI, Vasko. 1991. Vojaška organizacija na Slovenskem v 16. stoletju. Ljubljana: Matica slovenska.

SZABO, Gjuro. 1920. Sredovječni gradovi u Hrvatskoj i Slavoniji. Zagreb: Matica hrvatska. 
ŠTEFANEC, Nataša. 2001. Heretik Njegova Veličanstva. Povijest o Jurju IV. Zrinskom i njegovu rodu. Zagreb: Barbat.

ŠTEFANEC, Nataša. 2005. Demographic Changes on the Habsburg-Ottoman Border in Slavonia (c. 1570-1640). U Das Osmanische Reich und die Habsburger Monarchie in der Neuzeit. Akten des internationalen Kongresses zum 150-jährigen Bestehen des Institut für Österreichische Geschichtsforschung, ur. Marlene Kurz, Martin Scheutz, Karl Vocelka, Thomas Winkelbauer, 551-578. Beč - München: R. Oldenbourg Verlag.

ŠTEFANEC, Nataša. 2011. Država ili ne. Ustroj Vojne krajine 1578. godine i hrvatskoslavonski staleži u regionalnoj obrani i politici. Zagreb: Srednja Europa.

ŠTEFANEC, Nataša. 2014. Osmanski zapovjednici i struktura osmanske i habsburške vojske na hrvatskom dijelu krajišta (prema špijunskim izvješćima iz 1570-ih). U Ascendere historiam. Zbornik u čast Milana Kruheka, ur. Marija Karbić, Hrvoje Kekez, Ana Novak, Zorislav Horvat, 209-228. Zagreb: Hrvatski institut za povijest.

VARGA, Szabolcs. 2015. Studije o povijesti Sigeta i obitelji Zrinski u 16. stoljeću. Szigetvár: Szigetvári Várbaráti Kör, Pécsi Püspöki Hittudományi Főiskola, Pécsi Egyháztörténeti Intézet. 
The October-November 1556 military frontier payrolls: A contribution to the study of early military frontier history

The paper features transcripts of the October-November 1556 Military Frontier (Vojna krajina) payrolls, a table systematising the data found therein, and a brief introductory study. The study provides information on "Bulwark of Europe" and the documents analysed, and a comprehensive list of works dealing with the inception of the Military Frontier. It also briefly examines the power structures, ethnic make-up and the possibility of upward social mobility on the Military Frontier. Fortresses extant in 1556 are also listed.

Key words: Military Frontier, Slavonian Military Frontier, Croatian Military Frontier, military payrolls, Early Modern period, 1556

Ključne riječi: Vojna krajina, Slavonska vojna krajina, Hrvatska vojna krajina, krajiški popisi, rani novi vijek, 1556.

Petar Hegedić phegedic@ffzg.hr

Marta Jurković majurkovi@ffzg.hr

Nikola Ostojčić nostojic@ffzg.hr

Filip Šimunjak fsimunja@ffzg.hr

Studenti Filozofskog fakulteta Sveučilišta u Zagrebu 


\section{FILOZOFSKI FAKULTET SVEUČILIŠTA U ZAGREBU \\ ZAVOD ZA HRVATSKU POVIJEST \\ INSTITUTE OF CROATIAN HISTORY \\ INSTITUT FÜR KROATISCHE GESCHICHTE}

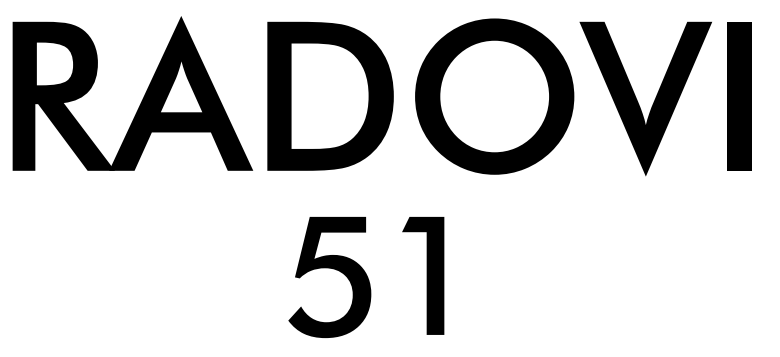

BROJ 2

ZAVOD ZA HRVATSKU POVIJEST

FILOZOFSKOGA FAKULTETA SVEUČILIŠTA U ZAGREBU

\section{FF press}

ZAGREB 2019. 


\title{
RADOVI ZAVODA ZA HRVATSKU POVIJEST FILOZOFSKOGA FAKULTETA SVEUČILIŠTA U ZAGREBU
}

\author{
Knjiga 51, broj 2
}

\author{
Izdavač / Publisher \\ Zavod za hrvatsku povijest \\ Filozofskoga fakulteta Sveučilišta u Zagrebu \\ FF-press \\ Za izdavača / For Publisher \\ Vesna Vlahović Štetić \\ Glavni urednik / Editor-in-Chief \\ Inga Vilogorac Brčić \\ Izvršni urednik / Executive Editor \\ Kornelija Jurin Starčević \\ Uredništvo / Editorial Board
}

Jasmina Osterman (stara povijest/ancient history), Trpimir Vedriš (srednji vijek/medieval history), Hrvoje Petrić (rani novi vijek/early modern history), Željko Holjevac (moderna povijest/ modern history), Tvrtko Jakovina (suvremena povijest/contemporary history), Silvija Pisk

(mikrohistorija i zavičajna povijest/microhistory and local history),

Zrinka Blažević (teorija i metodologija povijesti/theory and methodology of history)

Međunarodno uredničko vijeće / International Editorial Council

Denis Alimov (Sankt Peterburg), Živko Andrijašević (Nikšić), Csaba Békés (Budapest), Rajko

Bratož (Ljubljana), Svetlozar Eldarov (Sofija), Toni Filiposki (Skopje), Aleksandar Fotić

(Beograd), Vladan Gavrilović (Novi Sad), Alojz Ivanišević (Wien),

Egidio Ivetić (Padova), Husnija Kamberović (Sarajevo), Karl Kaser (Graz),

Irina Ognyanova (Sofija), Géza Pálffy (Budapest), Ioan-Aurel Pop (Cluj),

Nade Proeva (Skopje), Alexios Savvides (Kalamata), Vlada Stanković (Beograd),

Ludwig Steindorff (Kiel), Peter Štih (Ljubljana)

Izvršni urednik za tuzemnu i inozemnu razmjenu /

Executive Editor for Publications Exchange

Martin Previšić

Tajnik uredništva / Editorial Board Assistant

Dejan Zadro

Adresa uredništva/Editorial Board address

Zavod za hrvatsku povijest, Filozofski fakultet Zagreb, Ivana Lučića 3, HR-10 000, Zagreb Tel. ++385(0)1 6120191

Časopis izlazi jedanput godišnje / The Journal is published once a year

Časopis je u digitalnom obliku dostupan na / The Journal in digital form is accessible at Portal znanstvenih časopisa Republike Hrvatske „Hrčak“ http://hrcak.srce.hr/radovi-zhp

Financijska potpora za tisak časopisa / The Journal is published with the support by Ministarstvo znanosti, obrazovanja i športa Republike Hrvatske

Časopis je indeksiran u sljedećim bazama / The Journal is indexed in the following databases: Directory of Open Access Journals, EBSCO, SCOPUS, ERIH PLUS, Emerging Sources Citation Index - Web of Science 


\title{
Naslovna stranica / Title page by Marko Maraković
}

\section{Grafičko oblikovanje i računalni slog / Graphic design and layout Marko Maraković}

\author{
Lektura / Language editors \\ Samanta Paronić (hrvatski / Croatian) \\ Edward Bosnar (engleski / English)
}

Tisak / Printed by

Tiskara Zelina, Sv. Ivan Zelina

Naklada / Issued

200 primjeraka / 200 copies

Ilustracija na naslovnici

Muza Klio (Alexander S. Murray, Manual of Mythology, London 1898)

Časopis je u digitalnom obliku dostupan na Portalu znanstvenih časopisa Republike Hrvatske ,Hrčak“ http://hrcak.srce.hr/radovi-zhp

The Journal is accessible in digital form at the Hrcak - Portal of scientific journals of Croatia http://hrcak.srce.hr/radovi-zhp 